Парадокс демократических режимов: хрупкость и изменяемость (II)

\title{
Ш.Н. Эйзенштадт
}

Эйзенштадт Шмуэль Н., профессор Еврейского университета в Иерусалиме (Израиль).

Eisenstadt S.N. The Paradox of Democratic Regimes: Fragility and Transformability. - Sociological Theory, 1998, vol. 16, № 3 .

Окончание. Начало см. “Полис”, 2002, № 2, с. 67-81.

\section{Политический процесс в современных обществах: протестные движения и переопределение границ пространства политики}

Для того чтобы полностью постичь суть трений, характерных для динамики современных политических режимов, и прежде всего конфликта между хрупкостью и непрерывностью существования конституционно-демократических порядков, необходимо учитывать, что эти трения тесно связаны с рядом особенностей политического процесса, развивающегося в рамках таких режимов, в частности с постоянным взаимодействием центров и периферий и включением в основную символику современных режимов протестных символов.

Особое значение в данном контексте имеет центральная роль социальных движений, которые часто артикулируют дихотомии, противоречия и темы протеста, присущие позициям критиков и противников программы современности. Подобные движения представляют собой трансформировавшиеся в соответствии с современными условиями модификации различных еретических течений, традиционных для осевых цивилизаций, - прежде всего тех, которые стремились посредством политического действия добиться претворения или воссоздания на Земле Царства Божьего. Многие из них воплощают в себе поиск путей, способных приблизить некий конкретный общественный и политический строй к состоянию идеала, и такой поиск является важнейшим (хотя, конечно, не единственным) компонентом современного политического дискурса и процесса. Указанные движения - один из главных, а быть может, и главный носитель утопических представлений в современных обществах. Именно в них утопическое измерение современной политической жизни обнаружило свою сопряженность как с политическими структурами современности, так и с политическим плюрализмом. Отмеченная тенденция прямо коррелирует с харизматизацией центра как той ключевой арены, где подобные взгляды могут и должны найти свою реализацию.

Ведущей целью одной из разновидностей упомянутых движений было преобразование центров соответствующих обществ_1. Среди движений такого типа были и видевшие свою задачу в изменении принципов и оснований распределения власти в собственных обществах. Доминирующую роль в новейшие времена играли: (1) движения, добивавшиеся расширения круга лиц, включенных в центральную политическую структуру (посредством расширения избирательного права), и (2) социалистические и коммунистические движения, которые, наряду с этим, выступали за перестройку самой политэкономической модели. Предполагалось, что последнее может быть достигнуто путем коренной реорганизации экономических отношений и устранения наиболее иерархических позиций существующих центров. Другая группа движенийстремилась к преобразованию границ политических сообществ - прежде всего национальных или этнических.

В последнее время на авансцену выступили новые типы движений, постепенно усиливающие свою ориентацию на центр_2_. К данной категории относятся женские движения, а также движения всевозможных меньшинств; все они требуют изменения правил, регулирующих доступ к ресурсам и их распределение. В завершающие десятилетия XX в. на центр стали ориентироваться многие фундаменталистские и религиозные общинные движения, причем некоторые из них заняли доминирующие позиции. Подобные движения обычно не только выдвигают свои специфические требования, но и 
отстаивают более широкую, всеобъемлющую систему принципов, часто несущую на себе отчетливый отпечаток якобинства.

Помимо движений, ориентирующихся на центр, возникали и набирали силу религиозно-реформаторские, кооперативные и синдикалистские движения, добивавшиеся изменения тех или иных аспектов жизнедеятельности различных общественных секторов; анархистские движения, отвергавшие государство в принципе, а также популистские движения, делавшие упор на независимое участие [людей] в политическом процессе и выступавшие против господства бюрократии или центра. Для многих из них было характерно полное отрицание базовых посылок современности и их институциональных производных. Некоторые такие движения, в т.ч. уже давно сложившиеся религиозно-реформаторские, а также “синдикалистские” и большинство “постсовременных” (последние будут подробно проанализированы ниже), вроде бы отказались от ориентации на центр. Они были склонны подчеркивать необходимость создания новых [социальных] пространств, независимых от центра, но при этом зачастую посягающих на него. В действительности же эти два типа установок - ориентация на центр и акцент на конструировании новых [социальных] пространств - почти всегда частично совпадали. Конкретные темы, поднятые “отвернувшимися” от центра движениями, впоследствии были перехвачены теми, которые по-прежнему ориентировались на него.

Все эти непрерывно видоизменявшиеся движения существовали бок о бок друг с другом, образуя ключевой элемент политической и социальной динамики и дискурса современности, каким он был с конца XVIII в. Однако, поскольку их представления об общественном и политическом строе расходились, между ними в определенных условиях могли возникать острые идеологические и политические конфликты, как это было в 1930-х годах, когда вспыхнула жестокая идеологическая и политическая борьба между коммунистическим и фашистским движениями, или в период холодной войны, когда столкнулись коммунистическая и демократическая идеологии.

Институциональным фоном для развития рассматриваемых движений и их воздействия на политическую динамику своих обществ служили современные режимы в Европе, а затем - и за ее пределами. Они складывались прежде всего под влиянием процессов индустриализации, становления и экспансии капитализма, образования все новых современных политических режимов, формаций и международных систем и формирования соответствующих данным процессам новых типов коллективности — наций и наций-государств. Вне Западной Европы подобные движения возникали в связи с распространением империалистических, экономических, военных и идеологических аспектов современности по всему миру, а также столкновением между гегемонией Запада, с одной стороны, и традициями и цивилизациями Центральной и Восточной Европы, Азии, Африки - с другой. Указанные институциональные явления создавали не только исторические предпосылки для кристаллизации культурной и политической программы современности, но и ту арену, на которой данная программа - со всеми присущими ей антиномиями, трениями и противоречиями - разворачивалась, обретала законный статус и противостояла постоянно меняющимся социальным условиям. Именно трения и противоречия между базовыми положениями культурной и политической программы современности, а также между этими положениями и реальным ходом событий на различных национальных и международных институциональных площадках и привели к зарождению основных социальных движений.

Ключевая роль описываемых движений была тесно связана с двумя важнейшими особенностями политического процесса (развитию которых данные движения, со своей стороны, способствовали). Речь идет о: (1) потенциально высокой возможности политизации требований, выдвигаемых различными секторами общества, а также возникновения конфликтов между этими требованиями (вероятность такого поворота событий здесь выше, чем при любых других режимах, за исключением разве что тех, которые действовали в некоторых античных городах-государствах) и (2) непрерывной борьбе за переопределение пространства политики.

Тенденция к политизации требований проявляется в непрестанном переплетении борьбы за реализацию конкретных интересов отдельных граждан и групп с борьбой за утверждение конкурирующих толкований общей воли и коллективной идентичности (или идентичностей) [Pizzorno 1994]. С данным феноменом непосредственно связана и наблюдаемая во всех современных режимах мощная тенденция к постоянному пересмотру границ публичной политической сцены. Переход от концепции невмешательства государства в экономику (которая, разумеется, никогда полностью не проводилась в жизнь) к послевоенной кейнсианской модели государственного регулирования и институционализация государства всеобщего благосостояния быть может, лучшая иллюстрация такого пересмотра границ, но это лишь надводная часть айсберга [Maier 
1987; Przeworsky 1985]. На самом деле подобного рода изменения происходили в рассматриваемых обществах на протяжении всей их истории. В отличие от большинства других известных человечеству политических режимов, [в режимах современного типа] установление пределов политического само по себе является одним из главных средоточий публичных политических споров и столкновений.

Как показывает опыт государств всеобщего благосостояния, переопределению границ политического обычно сопутствовали попытки обновить трактовку всеобщего блага. В свою очередь изменение последней, как правило, требовало пересмотра набора прав, предоставляемых членам сообщества в сфере общественного перераспределения частных благ (прежде всего наделения граждан правом доступа к общественным благам), и принципов организации публичного пространства.

Требования перестройки области политического могли порождать (и нередко порождали) многочисленные конфликты и столкновения. Возникали трения между различными трактовками демократии (особенно между якобинскими и плюралистическими компонентами программы современности), противоречия между автономией гражданского общества и мощью государства, легитимационные споры между защитниками конституционных правил игры и носителями “первичных” концепций (выражаемых в примордиальных и/или сакральных терминах), а также расхождения между “рутинными” и “революционными” аспектами политического курса [см. Ackerman 1991; Eisenstadt 1996; Lasky 1970, 1976].

Широкое распространение [социальных] движений, активная артикуляция требований реорганизации сферы политического и постоянный вызов, обусловленный противоречиями между всеобъемлющей, интегралистской, а потенциально — и тоталитарной системой взглядов, с одной стороны, и приверженностью плюралистическим принципам - с другой, были присущи всем современным режимам и являлись базовыми элементами политической динамики в новейшую эпоху. Ни одной из современных конституционных и/или либеральных демократий так и не удалось (да и не могло удаться) полностью избавиться от якобинского компонента, особенно от его утопических аспектов. Они оказались не способны окончательно отказаться от тех составляющих коллективной идентичности, которые были связаны с ориентацией на некие примордиальные или сакральные, религиозные ценности, равно как от той легитимности, какую придают политическому строю подобного рода представления.

Повсеместность описанных выше трений в современных конституционно-демократических режимах свидетельствует о том, что такие режимы сталкиваются с двояким вызовом: идеологическим и конституционным. В первом случае речь идет об отрицании теми, кто отстаивает приоритет всеобей воли, легитимности плюрализма, во втором - о возможности разных толкований всеобщей воли и борьбы сторонников этих толкований за гегемонию. Первый вызов связан с необходимостью обеспечить приверженность ведущих политических акторов существующим правилам игры при сохранении способности режима к инкорпорации протеста в структуры центра, к переопределению рамок политического и, следовательно, к трансформации оснований своей легитимации. Подобная перестройка выражается прежде всего в переоценке границ политической сферы, в пересмотре прав и обязанностей членов сообщества, а также масштабов перераспределения личных благ и уровня доступа к ним. Указанные преобразования могут осуществляться по нескольким, нередко в чем-то пересекающимся направлениям: (1) через реконструкцию или изменение символов коллективной идентичности и центров; (2) через пересмотр по крайней мере некоторых принципов и форм легитимации режимов; (3) через пропаганду и осуществление политического курса, нацеленного на перераспределение ресурсов, и (4) через создание социальных ниш, в рамках которых различные группы смогут культивировать свои особые коллективные идентичности и собственные формы социальной, культурной или экономической активности.

Иначе говоря, второй вызов, с которым сталкиваются современные конституционно-демократические режимы, заключается в необходимости создания и поддержания некой единой для всех структуры, где могли бы конкурировать различные представления о всеобщем благе, не подрывая при этом функционирования системы. Возникает вопрос, на каком фундаменте (или фундаментах) — помимо соблюдения правил игры - строится общественное признание конституционно-демократических режимов? Быть может, им является сама множественность оснований легитимации - до тех пор, пока ни одно из них не преобладает?

Степень способности конституционно-демократических режимов к разрешению подобных противоречий преимущественно посредством своих ключевых институциональных структур или за счет собственного внутреннего изменения и определяет остроту главной угрозы непрерывности их существования. Более того, 
эта способность и олицетворяет собой парадокс изменчивости данной категории современных режимов. Суть дела заключается в том, что любая подобная трансформация, осуществляемая в рамках конституционно-демократических режимов, влечет за собой некую “металегитимацию”, выходящую за пределы установленных правил игры.

\section{Инкорпорация протеста: концепция политики как игры с ненулевой суммой и структурирование доверия в современных обществах}

Итак, способность к инкорпорации тем и символов протеста различных слоев населения в собственную структуру, в т.ч. попытки дать новую трактовку volonte generale, т.е. всеобщей воли, представляет собой как минимум один из важнейших критериев современных режимов, особенно

конституционно-демократических. Именно благодаря такой инкорпорации упомянутые режимы могут быть преобразованы при сохранении своей преемственности и без отказа от своих конституционных основ и принципов демократии.

Однако не все конституционно-демократические режимы в силах противостоять подобным вызовам. Многие (например США во время Гражданской войны или страны Центральной Европы в 1930-е годы) сбились с магистрального пути как раз потому, что оказались не в состоянии осуществить такую инкорпорацию. Сказанное подтверждает, что сложность и изменчивость проблем, вокруг которых разворачивается политическая борьба, многообразие целей, постоянный пересмотр границ политического обуславливают хрупкость и нестабильность конституционно-демократических режимов. Все эти процессы усугубляют проблему, на которую в свое время указывал А.Пшеворский [Przeworsky 1986, 1989; см. также O’Donnel, Schmitter 1986]: сам характер политической борьбы в таких режимах предполагает неопределенность результатов любого политического спора, любых конкретных выборов, любой дискуссии относительно проведения того или иного политического курса. Другими словами, никто из участников политической игры, ни одна из групп нынешних или потенциальных правителей не могут быть уверены в благоприятном для себя исходе политической схватки. В лучшем случае они могут рассчитывать на то, что им будет предоставлен шанс добиться своего на следующей стадии политического процесса. Инкорпорация новых тем и символов протеста, а также требований пересмотра границ политического, что, в свою очередь, неизбежно влечет за собой перераспределение ресурсов и изменение соотношения сил различных общественных групп и секторов, конечно, усиливает такую неопределенность. Одновременно все большую остроту приобретает вопрос о том, что именно должно побуждать политических акторов к добровольному отказу от своих властных позиций. Но, как ни парадоксально, породить подобную готовность может сама открытость современной политической игры.

При большинстве режимов политическая борьба обычно трактуется как относительно постоянная игра с нулевой суммой, когда выигрыш одного или группы игроков уравновешивается потерями соперников. Однако в современных конституционных демократиях диапазон потенциальных политических целей расширился до такой степени, что способен изменить сам характер политической игры. Конечно, в каждый конкретный период и в каждом конкретном демократическом обществе набор таких целей не безграничен, и одни проблемы оказываются в центре политической борьбы, тогда как другие отходят на задний план или исключаются. Самое общее ограничение диапазона целей касается проблемы соотношения между капитализмом и конституционной демократией. Конституционно-демократические режимы часто критикуются - преимущественно левыми - за то, что они так и не смогли подняться над капиталистическим строем. Вместе с тем некоторые - главным образом, из числа правых (по крайней мере, так было до недавних пор) - утверждают, что рыночная экономика является непременным условием существования конституционно-демократических режимов. Не вдаваясь здесь в подробный анализ этого принципиального и сложного спора, отмечу лишь тот факт, что капиталистические режимы конца XX столетия далеко отошли от тех образцов, которые были приняты на излете XIX и в начале XX в. Во всяком случае они были “приручены” социальными движениями (прежде всего - социалистическими) и под их влиянием подверглись настолько глубокой трансформации, что это повлекло за собой изменение набора политических целей и самого пространства политики в обществе. Подобные перемены указывают на возможность постоянного расширения масштабов политической игры.

Суть парадокса в том, что, хотя расширение рамок политической игры внесло в нее совершенно новый элемент - неопределенность, — который действительно может увеличить хрупкость рассматриваемых режимов, это расширение способно также изменить характер политической игры, превратив ее в игру с ненулевой суммой; и в случае ее принятия в таком качестве будет минимизирована возможность тотального 
поражения любой из сторон. Развитие данной концепции, которое неизбежно повлечет за собой прочную ориентацию на открытость будущего, в состоянии стимулировать политических акторов к передаче власти в соответствии с конституционными правилами игры. Хотя вследствие инкорпорации новых требований и пересмотра границ политического они могут утратить свои властные позиции, их гибкость в дальнейшем позволит им вернуться к власти, дабы воплощать в жизнь собственные представления и добиваться новых целей.

Таким образом, общества, где возникает и укореняется понимание политики как игры с ненулевой суммой, обычно обретают способность к инкорпорации протестных символов и различных требований, особенно если они касаются перестройки пространства политики. Это увеличивает потенциальную изменяемость конституционно-демократических режимов и тем самым позволяет им лучше справляться с главными вызовами, ставящими под угрозу непрерывность их существования.

Установление конституционно-демократических режимов и принятие конституций сами по себе отнюдь не гарантируют развития представлений о политике как об игре с ненулевой суммой и соответствующих возможностей для инкорпорации протеста. Детальный анализ условий, способствующих или препятствующих утверждению подобных представлений и непрерывности существования [конституционно-демократических режимов], выходит за рамки настоящего очерка. Однако представляется уместным высказать ряд предварительных соображений относительно характера этих условий.

Некоторые условия, или предпосылки, демократии подробно проанализированы в научной литературе. Главный упор обычно делается на: (1) распределение ресурсов и власти в обществе, прежде всего на обеспечение различных акторов постоянным доступом к ресурсами, необходимым для вступления в политическую игру и ее проведения; (2) отношения между основными центрами общественной и экономической власти и центральными политическими институтами и аренами; (3) создание и “воспроизводство” автономных публичных сфер.

Важнейшей среди перечисленных в первом пункте данного перечня переменной является положение о недопустимости монополизации ключевых ресурсов и источников власти в обществе какой-либо группой или сектором; это предполагает обязательное наличие множества различных властных центров, которые потенциально способны оставаться вне сферы влияния политической власти (будь она абсолютистской, республиканской или революционно-коммунитарной), но которые - тоже потенциально — имеют доступ к центрам своих обществ. Другим критически значимым условием непрерывности существования конституционно-демократических режимов выступает постоянное расширение независимого доступа социальных групп к политической сцене (или сценам), причем речь идет не только о формальном избирательном праве, но и о реальной возможности прямого участия и/или влияния. Для того чтобы обеспечить такой доступ, необходимы развитие и постоянное функционирование институциональных структур и организаций, служащих связующими звеньями между общественными секторами и политической сценой. Особую роль в данном контексте играют автономные публичные арены, не встроенные ни в государственные структуры, ни в “установленные” статусные или корпоративные рамки какого-либо из общественных секторов. Кроме того, дабы гарантировать их непрерывное развитие, требуется, чтобы они были свободны от контроля со стороны государства, хотя те, кто на них действует, могут иметь доступ к последнему. Наиболее важными из указанных “арен” являются ключевые органы политического представительства и политической организации, такие как партии и другие типы политических ассоциаций, а также каналы коммуникации и дискурса, по которым движется политически значимая информация.

Постоянный процесс публичной коммуникации внутри и между подобными общественными площадками и объединениями, а также - на другом уровне - между ними и центрами облегчает свободный выход основных секторов общества на политическую сцену. Наличие указанных механизмов обеспечивает их постоянное участие [в политической жизни] и способность требовать отчета от правителей.

Значение рассмотренных выше условий для поддержания непрерывного существования конституционно-демократических режимов детально проанализировано, но их воздействие на развитие представлений о политике как об игре с ненулевой суммой еще систематически не исследовано. Я полагаю, что критически важную роль в формировании и развитии подобных представлений играет постоянное воссоздание солидарности и доверия, связывающих между собой различные слои общества, а их — c центрами и институтами, олицетворяющими собой более широкие институциональные площадки. 
Солидарность и доверие не приходят сами собой, особенно в демократических режимах. Приведу в данной связи мнение М.Уоррена, высказанное им в частной переписке: “Парадокс в том, что соотношение между демократией и доверием далеко не однозначно. Конфликты указывают на то, что доверие отсутствует, а быть может — и нецелесообразно; но, тем не менее, любые попытки разрешить их по принципу игры с ненулевой суммой строятся на постулатах о том, что (а) конфликт сдерживается другими отношениями (и институтами), которые включают в себя доверие, и (б) сам процесс урегулирования конфликта порождает доверие. При отсутствии такой возможности демократия оказывается в лучшем случае непрочной”.

Таким образом, возможность постоянного восстановления доверия при демократических режимах определяется особым институциональным фоном - прежде всего наличием относительно стабильных институциональных структур, которые обеспечивают участие основных социальных секторов в выработке и интерпретации правил политической игры. В свою очередь, образование подобного фона зависит от комбинации упомянутых выше структурных факторов, т.е. (1) автономности, сплоченности и доступности центра; (2) открытости основных элит по отношению друг к другу, а также по отношению к более широким слоям населения и (3) четкости и прозрачности построения в соответствующем обществе коллективной идентичности. Здесь я хотел бы сосредоточить внимание на анализе одной из только что перечисленных групп факторов, а именно на способах определения символических границ возникающих общностей современного типа. В данной связи наибольший интерес представляет вопрос о том, в какой мере в том или ином сообществе переплелись между собой примордиальные, религиозные, гражданские и универсалистские компоненты коллективной идентичности и, что особенно важно, не был ли какой-то из них абсолютизирован и противопоставлен своими сторонниками другим компонентам. Во всех современных европейских обществах самыми значимыми с точки зрения долговечности или краха конституционных режимов аспектами установления границ сообщества и выработки коллективной идентичности были формы соединения современных универсалистских и гражданских компонентов последней не только с ее более древними, религиозными составляющими, но и с примордиальными элементами, переосмысленными и преобразованными в ходе процесса модернизации в национальные и/или этнические.

Как показали С.Липсет и С.Роккан [Lipset, Rokkan 1967; Rokkan 1975], существует тесная корреляция между конкретными способами установления границ сообщества, а также соотношением различных компонентов коллективной идентичности и тем, каким образом [в том или ином случае] преодолевались великие религиозные расколы и схватки периодов Реформации и контрреформации и решалась проблема взаимоотношений между национальными, цивилизационными и религиозными общностями. Кроме того, на характер коллективной идентичности повлияли такие факторы, как открытость или, наоборот, жесткость современных центров и сформировавшихся внутри них элит.

Использование одной из моделей “урегулирования”, получившей распространение во Франции и особенно - в Германии____, привело к тому, что религиозный вопрос (раскол между католиками и протестантами или традиционными религиозными группами и “секуляристами”) стал причиной постоянной концентрации внимания на разногласиях и источником политической борьбы между довольно жесткими конкурирующими центрами, а также между соперничающими элитами по вопросам, касающимся построения символов коллективной идентичности и степени независимости религиозных групп в сферах образования и заключения браков. Для другой модели решения религиозной проблемы, принятой преимущественно в католических странах, где взяла верх контрреформация, — прежде всего в Испании, Португалии и во многих областях Италии, — было характерно провозглашение католических символов и институциональных структур единственно допустимыми для данной национальной общности, что, соответственно, повлекло за собой подавление религиозных меньшинств [см. Grew 1963, 1978; Magnone 1961; Delzell 1965; Salvatorelli 1970; Beals 1971; Payne 1978; Derrick 1959].

Оба указанных подхода резко контрастировали с теми, которые использовались в протестантских странах Западной Европы, где успешно институционализировались конституционные режимы. Всем этим странам была присуща относительная, или частичная, деполитизация религиозного раскола, что привело, с одной стороны, к провалу попыток насадить единомыслие, свойственное некоторым протестантским сектам, и, следовательно, к ослаблению интегралистских ориентаций, а с другой - к укреплению эгалитарных и индивидуалистических компонентов, которые были сильны в других протестантских группах.

Как уже упоминалось, описанные модели “урегулирования” религиозных конфликтов во многом коррелировали с типами коллективной идентичности в соответствующих европейских обществах. Так, для 
строения коллективных идентичностей, сложившихся в Англии, Голландии, Швейцарии и Скандинавских странах, характерно тесное переплетение гражданских и универсалистских компонентов с

примордиальными и религиозными (без отвержения последних); вот почему там возникло относительно широкое пространство для плюралистических механизмов [Graubard 1986; Kuhnle 1975; Rothstein 1996; Rustow 1956; Thomas 1978; Thompson 1968; Thompson 1943, 1960; Geyl 1958; Beloff 1954; Daalder 1971; Bergier 1974; Lehmbruch 1972; Lorwin 1971; Steiner 1974]. В этих странах сравнительно успешно, пусть и не без некоторых трений, сосуществовали и перемешивались между собой примордиальные и территориально-этатистские концепции и символы коллективной идентичности и развивались сильные центры, внутри которых важную роль играли представительные институты. Различные элиты и носители конкурирующих концепций были инкорпорированы в основную конституционную структуру общества и действовали по ее правилам.

Подходы к урегулированию религиозного конфликта повлияли и на то, в какой мере [в том или ином обществе] “традиционно” религиозные и/или интегралистские революционные ориентации воспринимались в качестве своего рода неизбежных монополий — и необходимого условия создания символов коллективной идентичности. В протестантских странах придерживавшимся подобных ориентаций институтам, таким как церковь или отдельные политические партии, было отказано в праве вето при определении границ сообщества. Ни религиозные, ни революционные символы или установки никогда не оказывались там в центре постоянных споров по поводу выработки коллективной символики (хотя, разумеется, трения между ними всегда сохранялись), а сами подобные споры обычно разрешались в рамках недавно оформившихся государств и современных конституционных институтов. Иными словами, религиозные и революционные ориентации и символы постепенно переплетались между собой, а также с примордиальными и гражданскими компонентами легитимации, что вело к ослаблению их интегралистских и абсолютистских элементов.

В некоторых обществах — особенно в Центральной Европе и прежде всего в Германии — процесс формирования коллективной идентичности современной нации-государства сопровождался постоянной конфронтацией между примордиальными, гражданскими и универсалистскими компонентами, а также между религиозными группами и “традиционно” религиозными и современными универсалистскими элементами. В этих случаях возникала устойчивая тенденция к кризисам и сбоям в функционировании различных типов конституционных механизмов. Трения между носителями примордиальных и интегралистских компонентов коллективной идентичности дали толчок к появлению движений, абсолютизировавших ту или иную ориентацию, приписывая ей доминирующую роль. Примордиальные элементы возобладали в самых “традиционалистских” авторитарных режимах и в тоталитарных (фашистских или национал-социалистских) движениях с отчетливой расистской окраской; абсолютистские универсалистские концепции распространялись разнообразными “левацкими” якобинскими движениями.

Подобное противостояние часто отражало расхождения между участнической и плюралистической трактовками демократии, тем более что для первой нередко характерны якобинские установки и тяготение к авторитаризму и тоталитаризму. О том, какие проблемы порождает постоянная конфронтация якобинских и традиционалистских составляющих легитимации современных режимов - даже при относительно прочном государственном устройстве и наличии устойчивых коллективных идентичностей и границ, — яснее всего говорит, наверное, опыт Франции. Прежде всего этот опыт указывает на то, что в таких условиях крайне затруднено развитие плюралистических тенденций и структур. Соответственно, институционализация стабильного конституционно-демократического режима здесь проблематична или, в лучшем случае, протекает весьма бурно.

Поскольку конкретные модели выстраивания коллективной идентичности в европейских странах складывались на основе постоянной обратной связи, они тесно коррелировали со степенью автономии центров, а также открытости и доступности таких центров для элит и различных социальных слоев. Оба последних фактора - то есть открытость и доступность - имеют ключевое значение для формирования и перестройки институциональных структур конституционной демократии, особенно когда речь идет о постоянном воспроизводстве публичной сферы (или сфер), автономной от государства и в то же время имеющей независимый выход на политическую сцену, пусть даже характер этой сферы (или сфер) определяется спецификой того общества, в котором она действует, и происходящих в нем изменений.

Различные комбинации рассмотренных выше факторов играют решающую роль в процессе формирования и восстановления доверия между гражданским обществом и государством. Не менее решающей является их 
роль в успешном распространении в обществе отношений доверия, необходимых для становления и поддержания представлений о политике как об игре с ненулевой суммой, а следовательно — для устойчивости конституционных демократий. От комбинации данных факторов зависит, насколько велики окажутся шансы на то, что на любом этапе глубоких социальных трансформаций (1) изменение соотношения компонентов коллективной идентичности и основ легитимации политического режима будет происходить без тотальной конфронтации между отдельными общественными секторами; (2) не прекратится развитие определенных базовых ориентаций, подготавливающих почву для формирования единой коллективной идентичности либо признания различными слоями населения некой всеобщей идеи, или “текста”. Именно появление такого всеобщего “текста”, в сочетании с дисперсией властных центров и рассредоточением власти, богатства и престижа, и способствует постоянной перестройке сферы политического в рамках существующих конституционных институтов. Кроме того, с его появлением складываются благоприятные условия для непрерывного переосмысления и уточнения правил политической игры, а следовательно - для металегитимации этих правил.

Относительная значимость описанных выше факторов и концепций организации власти - например, синхронности создания политических центров и различных общностей — может существенно варьировать в зависимости от страны и конкретных исторических обстоятельств. Прежде всего, нередко неодинаковой бывает роль внутренних и внешних предпосылок создания тех рамок, в которых происходит выработка необходимых [для существования конституционно-демократических режимов] навыков и привычек. В самом деле, один из наиболее интересных феноменов нашего времени, который, однако, во многом воспроизводит прежний исторический опыт, заключается в огромном воздействии международного окружения (в частности, исходящего от него давления в направлении демократизации) на формирование соответствующих структур - даже в ситуациях, когда внутренние предпосылки к этому сравнительно слабы.

Вместе с тем наличие указанных факторов само по себе отнюдь не гарантирует, что между задействованными в политическом процессе акторами возникнет то доверие, которое требуется для поддержания непрерывного существования соответствующего режима. Структура такого доверия и его связь с распределением ресурсов часто определяется различного рода историческими случайностями, особенно последствиями того или иного относительно острого внутреннего конфликта, а также воздействием международных событий. Процесс изменения представлений и привычек людей по ходу развития в Европе конституционных режимов, более 30 лет назад проанализированный Д.Растоу [Rustow 1970], а затем - М.Бертоном, Р.Гантером и Дж.Хайли [Burton, Gunther, Highley 1992], имел первостепенное значение для обретения и утверждения доверия.

Непрерывное воссоздание доверия, а следовательно - и выработка представлений о политике как об игре с ненулевой суммой и обусловленная этим изменяемость конституционно-демократических режимов всегда происходили под влиянием вышеперечисленных факторов. Однако конкретное соотношение указанных факторов, равно как и конкретные модели формирования доверия в целом в различных обществах во многом варьируют. В данном разделе основное внимание было уделено моделям, сложившимся в европейских странах. В США, Японии, Индии и Израиле рассмотренные процессы протекали несколько иначе, но их детальный анализ выходит за рамки настоящего очерка.

\section{Социальные изменения, политический процесс и возможность размывания доверия и эрозии публичной сферы при конституционно-демократических режимах: тенденции к разложению демократии в современных обществах}

Специфика в принципе неостановимого развития конституционно-демократических режимов такова, что наличие благоприятных условий для функционирования данных режимов в некие конкретные исторические периоды само по себе не гарантирует непрерывности их существования и воспроизводства. Конечно, успешная институционализация конституционно-демократического строя во многом способствует закреплению такого рода условий, особенно если речь идет о признании легитимности режима, о доверии к правилам политической игры и о понимании политики как игры с ненулевой суммой. Однако в недрах любой конституционной демократии могут развиваться процессы, размывающие их. В самом деле, уже тот факт, что современные общества (и, в частности, основные параметры политического процесса в странах с конституционно-демократическим устройством) претерпевают постоянные изменения, может подорвать некогда благоприятные условия для постоянного восстановления доверия. 
Во-первых, поскольку современные режимы развиваются в обстановке непрестанных перемен и поскольку внутри них происходят социальные, политические и экономические сдвиги, распределение власти в этих режимах тоже может меняться, что ведет к эрозии значительной части существующих властных центров. Более того, те самые меры, которые изначально были нацелены на ослабление имеющихся полумонополистических центров власти (например, меры, связанные с утверждением государства всеобщего благосостояния), нередко до такой степени усиливают властные полномочия различных политических и административных органов государства, что оказываются разрушены многие независимые базы власти. Угроза такого поворота событий в первую очередь ассоциируется с бюрократизацией важнейших сфер общественной жизни, включая область политики; и, как видно из работ А.де Токвиля, К.Маркса и М.Вебера, страх, порожденный призраком подобной бюрократизации, пронизывает современный социальный дискурс. Понятно, что с образованием тоталитарных режимов этот страх получил дополнительные основания.

Вместе с тем перспектива сверхконцентрации власти потенциально связана и с одним из центральных нервов демократического процесса — с производством и распространением информации, с доступом к ней, а также с растущей профессионализацией и “технократизацией” знаний и сведений, имеющих отношение к политическому процессу. Если эксперты и политические лидеры объявят, что знания, которыми они располагают, выходят за пределы понимания широких кругов общественности, и общество с ними согласится, то результатом могут стать распространение политической апатии и отказ от участия в политике вообще. Кроме того, подобная ситуация чревата нарушением равновесия на самой политической сцене, прежде всего соотношения сил различных ветвей власти, и усилением мощи исполнительных органов.

Во-вторых, масштабные перемены зачастую влекут за собой подрыв автономности и самобытности различных элит, центра и разнообразных публичных арен. Попытки пересмотреть границы политического - например, за счет расширения корпуса избирателей - способны привести к эрозии автономных секторов гражданского общества и существующих политических арен, а также помешать перестройке отношений между гражданским обществом и государством. В таких случаях приверженность существующим правилам игры и соблюдению баланса между государством и гражданским обществом может вступить в противоречие с новыми требованиями, выдвигаемыми недавно возникшими социальными силами. Во всех секторах общества, как старых, так и новых, могут возникнуть тенденции к представительству узкокорпоративного или статусного окружения, что ослабит то исходно одобрительное отношение к наличию данных секторов, которое присутствовало при формировании общих структур и центров.

Во всех подобных ситуациях у тех, кто требует пересмотра границ политического, начинает возникать подозрение, что действующие представительные институты не служат общественному благу. Весьма часто носители власти - а нередко ими бывают сильные полумонополистические, олигархические группы активно поддерживают набор прав, прежде всего права собственности, которые обеспечивают им преимущество перед вновь образующимися группами. Новые же группы, оспаривающие приоритет властвующих, склонны доказывать важность другого набора прав, противопоставляя их тому, что они объявляют узкими интересами небольшого клуба, членство в котором зарезервировано, де-юре или де-факто, только за представителями высших классов. Суть подобной позиции, которой, естественно, придерживаются преимущественно левые критики либерально-демократических режимов, отражает знаменитый афоризм А.Франса о том, что нищий, ночующий под мостом, имеет “равные” права с богатым буржуа. В свою очередь “старые” группы пытаются представить себя выразителями общественного блага в противовес “новичкам”, которых они обвиняют в том, что те заботятся только о своих собственных эгоистических интересах — пусть даже разделяемых многими - и стремятся использовать представительные институты для их продвижения.

В таких условиях перестройка гражданского общества практически неизбежно сопровождается конфронтацией между базовыми концепциями демократии - прежде всего между конституциональной и участнической, - а также, в более общем плане, между плюралистическими и якобинскими ориентациями, заложенными в программе современности. Все эти потенциальные повороты событий олицетворяют собой парадокс изменяемости современных конституционных режимов, суть которого, как мы видели, состоит в том, что любая трансформация последних влечет за собой металегитимацию, выходящую за пределы (действующих) правил игры, и в то же время осуществляется через эти самые институции.

Указанные процессы могут дать толчок к частичному изменению режима в странах с демократическим устройством, как это было, например, при переходе от Четвертой к Пятой республике во Франции. 
Аналогичные сдвиги происходили во многих современных обществах: в Соединенных Штатах, Израиле, Индии и - в менее драматической форме - в Европе. Важнейшими компонентами такого рода режимных преобразований являются: (1) ослабление партий и представительных институтов по сравнению с прямыми политическими действиями и непосредственными отношениями различных политических акторов; (2) усиление средств массовой информации и их роли в политическом процессе и (3) повышение значимости исполнительной власти при возможном возрастании полномочий судебной системы.

Подобные изменения режимов непосредственно сопряжены с далеко идущими сдвигами, затрагивающими многие аспекты социального строения современных обществ. Важнейшими рубежами здесь, вероятно, выступают период накануне второй мировой войны и нынешний, “современный” этап, иногда называемый “постсовременным” [Eisenstadt 1988 1993]. К числу наиболее значимых из упомянутых сдвигов относятся: размывание прежних, когда-то относительно четких, строго определенных и единообразных представлений о жизненном пути (и тем самым - границ семьи, сообщества, локальной и социальной организации) и сопутствующая этому тенденция к выпадению большинства важнейших общественных ролей из всеобъемлющей - в рамках данного общества - символической и институциональной среды. Роли, обусловленные родом занятий, семейным положением, полом, местом проживания, все заметнее отделяются от сословных, классовых и партийно-политических региональных структур. Такие роли все больше и больше оформляются в постоянно меняющиеся кластеры с относительно слабой ориентацией на общие структуры и - особенно - на социетальные центры. Переоценка ролей и образование ролевых кластеров, прежде всего профессиональных и гражданских, - взаимосвязанные феномены, равно как и растущее отмежевание политических центров от социальных и культурных сообществ и развитие новых очагов культурной и социальной идентичности поверх существующих политических и культурных границ.

Совокупность этих изменений в символическом определении различных сфер общественной жизни, в сочетании со структурными сдвигами, ведет к усиливающейся диверсификации процесса стратообразования и формированию перекрещивающихся политических, секторальных и профессиональных структур. Для нынешней ситуации характерна гораздо большая степень разобщенности между профессиональной, культурной и политической сферами жизни, чем это было в эпоху “современного”, “индустриального” общества, когда различные страты имели относительно самостоятельные культурные традиции и объединялись лишь вокруг самых общих и широко понимаемых политических символов. Разброс между культурными ценностями отдельных страт существенно сократился, а их стремление к участию во всех проявлениях и областях культурной жизни вообще и массовой культуры — в частности, неуклонно растет.

Таким образом, общественные страты постоянно перестраиваются, трансформируя и видоизменяя свои взаимоотношения и порождая новые формы сопряжения социальной структуры, культуры, политической активности и политической организации. В результате профессионального распыления они по большей части утратили свои всеобъемлющие политико-идеологические ориентации, соответственно, упало и значение той проблематики, вокруг которой разворачивались классовые конфликты и классовая борьба и которая традиционно была сфокусирована на государстве как распределяющей и — в меньшей степени регулирующей инстанцией. Одновременно сократился и раскол между “левыми” и “правыми” в целом и ослабла тесная взаимосвязь между его наличием и перестройкой центра, столь сильно проявлявшаяся в Европе и Японии.

Кульминацией всех описанных выше трансформаций стало изменение характера протестных движений. Начало этому процессу положили студенческие бунты 1960-х годов, а затем он охватил женские и экологические движения, движения сторонников расширения участия работников в управлении производством, борцов за решение тех или иных проблем локальных сообществ, и т.д. В отличие от прежних, “классических”, социальных движений индустриальных обществ эпохи модерна, которые с присущей им конфликтно-идеологической направленностью фокусировали внимание на центре и его перестройке, новые движения ставят во главу угла расширение системного пространства общественной жизни и проблему участия. Наиболее ярким проявлением подобной смены ориентаций был, наверное, перенос акцента с вопросов повышения уровня жизни, что олицетворяло собой суть непрерывного технологическо-экономического прогресса и было так характерно для 1950-х годов, на проблемы улучшения “качества жизни”; в 1970-е годы данная трансформация обозначалась как переход от “материальных” к “постматериальным” ценностям. Все упомянутые движения отвергают логику перестройки центра, сосредоточивая свои усилия на создании новых социальных пространств. Вместе с тем такого рода перемены сами по себе являются показателем другого серьезного сдвига: политический центр, оставаясь главной инстанцией, занимающейся распределением ресурсов, уже утратил ту харизму, которая бы 
позволила ему, как прежде, притягивать к себе основное внимание различных социальных движений или, коли на то пошло, широких слоев общественности.

Указанные перемены прямо коррелируют с возможностью частичного изменения режима, о которой шла речь выше. В наиболее крайних случаях их сочетание способно также привести к тому, что, пользуясь удачным выражением Л.Даймонда [Diamond 1993; см. также Linz, Stepan 1996], можно назвать деконсолидацией институциональных и ассоциативных оснований конституционно-демократических режимов, и - тем самым - к ослаблению или размыванию конституционных компонентов, жизненно необходимых для реализации принципа верховенства права, таких как невмешательство политических органов в общественные и частные дела и т.п.

Как отмечал Р.Дарендорф [Dahrendorf 1990], подобное ослабление или даже размывание основ и принципов гражданского общества наблюдается сегодня во многих современных конституционных демократиях. Например, в странах Латинской Америки [см. Huber, Rueschmeyer, Stephens 1997] описанная тенденция, похоже, проявляется в усилении формальных и ослаблении участнических аспектов демократии. Как ни парадоксально, все это происходит в ситуации, когда идеологические, прежде всего тоталитарные фашистские или коммунистические, — противники конституционной демократии уже сошли с исторической сцены. Аккумуляция данных процессов может породить разочарование и апатию, которые, в свою очередь, способны повлечь за собой подрыв доверия к центральным институтам или — другая крайность - поворот в сторону всевозможных экстремистских движений и развитие новых форм политической активности.

Вполне вероятно, что мы являемся сегодня свидетелями становления — и в конституционно-демократических, и во многих полудемократических, авторитарных режимах по всему миру - новых моделей политической активности, тесно связанных с далеко идущими “культурными” сдвигами, а также с изменением оснований легитимации таких режимов. Однако, хотя эти тенденции и имеют непосредственное отношение к рассматриваемым здесь проблемам, их анализ выходит за рамки настоящего исследования.

Ackerman B. 1991. We The People. Cambridge.

Apter D. 1994. Revolutionary Discourse in Mao’s Republic. Cambridge.

Aronowitz S. 1992. The Politics of Identity: Class, Culture, Social Movements. N.Y.

Assies W. 1992. To Get Out of the Mud. Neighbourhood Associativism in Recife, 1964 - 1988. Amsterdam.

Banks O. 1981. Faces of Feminism: A Study of Feminism as a Social Movement. Oxford.

Bash H. 1995. Social Problems and Social Movements: An Exploration into the Sociological Construction of Alternative Realities. Atlantic Highlands.

Beals D. 1971. The Risorgimento and the Unification of Italy. L.

Beloff M. 1954. The Age of Absolutism: 1660 — 1815. L.

Bennett G. 1976. “Yundong” Mass Campaign in Chinese Communist Leadership. Berkeley.

Bergier J. 1974. Naissance et croissance de la Suisse industrielle. Bern.

Berry B. 1992. America’s Utopian Experiments: Communal Havens from Long-Wave Crises. Hanover.

Bien D., Grew R. 1978. France. - Grew R. (ed.) Crises of Political Development in Europe and the United States. Princeton.

Boggs C. 1986. Social Movements and Political Power: Emerging Forms of Radicalism in the West. Philadelphia.

Brovkin V. 1994. Behind the Front Lines of the Civil War: Political Parties and Social Movements in Russia, 1918 - 1922. Princeton. 
Burton M., Gunther R., Highley J. 1992. Elites and Democratic Consolidation — Latin America and Southern Europe, An Overview. - Highley J., Gunther R. (eds.) Elites and Democratic Consolidation in Latin America and Southern Europe. Cambridge.

Craig G. 1955. The Politics of the Prussian Army. Oxford.

Daalder H. 1971. On Building Consociational Nations: The Case of the Netherlands and Switzerland. — International Social Science Journal, vol. 23.

Dahrendorf R. 1990. The Modern Social Conflict: An Essay on the Politics of Liberty. Berkeley.

Della Porta D. 1995. Social Movements. Political Violence, and the State: Comparative Analysis of Italy and Germany. Cambridge.

Delzell C. (ed.) 1965. The Unification of Italy, 1859 - 1861. N.Y.

Derrick M. 1959. The Portugal of Salazar. L.

Diamond L. 1993. Conclusion. Causes and Effects. — Diamond L. (ed.) Political Culture and Democracy in Developing Countries. Boulder.

Eisenstadt S.N. 1988. Revolutionary Movements and Radicalism in Post-Industrial Societies. — International Foundation of Social Sciences. International Symposium on Fears and Hopes. October.

Eisenstadt S.N. 1993. Small Estates in the "Post-Modern” Era. — Kleinstaat, Lichtenstein Politische Schriften, Bd. 16.

Eisenstadt S.N. 1996. Barbarism and Modernity. — Society, vol. 33, № 4.

Elliot W. 1968. The Pragmatic Revolt in Politics: Syndicalism, Fascism, and the Constitutional State. N.Y.

Geyl P. 1958. The Revolt of the Netherlands. N.Y.

Gillis J. 1971. The Prussian Bureaucracy in Crisis. 1940 - 1860. Stanford.

Gillis J. 1978. Germany. — Grew R. Crises of Political Development in Europe and the United States. Princeton.

Goldberg R. 1991. Grassroots Resistance: Social Movements in Twentieth-Century America. Belmont.

Graubard S. (ed.) 1986. Norden — The Passion for Equality. Oslo.

Grew R. 1963. A Sterner Plan for Italian Unity. Princeton.

Grew R. 1978. Italy. — Grew R. (ed.) Crises of Political Development in Europe and the United States. Princeton. Hamerow T. 1958. Restoration, Revolution, Reaction. Princeton.

Hamerow T. 1969. The Social Foundations of German Unification, 1858 - 1871. Princeton.

Hoffman S. Protest in Modern France. - Kaplan M. The Revolution in World Politics. N.Y.

Huber E., Rueschemeyer D., Stephens J.D. 1997. The Paradoxes of Contemporary Democtacy: Formal, Participatory, and Social Democracy. - Comparative Politics, vol. 29, № 3.

Jackson R. 1992. The 1960s: An Annotated Bibliography of Social and Political Movements in the United States. Westport.

Jelin E. (ed.) 1990. Women and Social Change in Latin America. Geneva.

Joll J. 1964. The Anarchists. L. 
Joppke C. 1995. East German Dissidents and the Revolution of 1989: Social Movements in a Leninist Regime. N.Y. Karst K. 1993. Law’s Promise, Law’s Expression: Visions of Power in the Politics of Race, Gender and Religion. New Haven.

Kesavanarayana B. 1976. Political and Social Factors in Andhra (1900 - 1956). Vijayawada.

Kostunica V. 1985. Party Pluralism or Monism: Social Movements and the Political System in Yugoslavia. 1944 1949. Boulder.

Koury E. 1970. The Patterns of Mass Movements in Arab Revolutionary-Prograssive States. Hague.

Kuhnle S. 1975. Patterns of Social and Political Mobilization: A Historical Analysis of the Nordic Countries. Beverly Hills.

La Botz D. 1995. Democracy in Mexico: Peasant Rebellion and Political Reform. Boston.

Lasky M. 1970. The Birth of a Metaphor: On the Origins of Utopia and Revolution. — Encounter, vol. 34, № 2.

Lasky M. 1976. Utopia and Revolution. Chicago.

Lehmbruch G. 1972. Proporzdemokratie: Politische System und politische Kultur in der Schweiz und in Osterreich. Tubingen.

Linz J.J., Stepan A. 1996. Problems of Democratic Transition and Consolidation. Baltimore.

Lipset S.M., Rokkan S. (eds.) 1967. Party Systems and Voter Alignments. N.Y.

Lorwin V. 1954. The French Labor Movement. Cambridge.

Lorwin V. 1971. Segmented Pluralism. Ideological Cleavage and Political Behavior in the Smaller European Democracies. - Comparative Politics, vol. 3.

Luethe H. 1957. France Against Herself. N.Y.

Magnone G. 1961. Italy. — Cole T. (ed.) European Party Systems. N.Y.

Maier C.S. (ed.) 1987. Changing Boundaries of the Political. Cambridge.

Mathew J. 1986. Ideology, Protest and Social Mobility: Case Study of Mahars and Pulayas. New Delhi.

Morgan E. 1991. The 60s Experience: Hard Lessons about Modern America. Philadelphia.

Morris A., McClurg Muller C. (eds.) 1992. Frontiers in Social Movement Theory. New Haven.

Neumann S. 1956. Germany: Changing Patterns and Lasting Problems. — Modern Political Parties. Chicago.

Neumann S. 1962. The German Political System. — Beer S., Ulam A. (eds.) Patterns of Government: The Major Political Systems of Europe. N.Y.

O’Donnel G., Schmitter P. 1986. Transition from Authoritarian Rule: Tentative Conclusions about Uncertain Democracies. Baltimore.

Opp K. 1995. Origins of a Spontaneous Revolution, East Germany, 1989. Ann Arbor.

Payne S. 1978. Spain and Portugal. - Grew R.(ed.) Crises of Political Development in Europe and the United States. Princeton.

Pitts J. 1963. Continuity and Change in Bourgeois France. — In Search of France. Cambridge (MA). 
Pizzorno A. 1994. Le radici della politica assoluta. Milano.

Przeworski A. 1985. Capitalism and Social Democracy. Cambridge.

Przeworski A. 1986. Some Problems in the Study of the Transition to Democracy. - Transitions from Authoritarian Rule: Comparative Perspective. Baltimore.

Przeworski A. 1989. Democracy as a Contingent Outcome of Conflicts. — Elster J., Slagstad R. (eds.) Constitutionalism and Democracy. Cambridge.

Reed T. Fifteen Jugglers, Five Believers: Literary Politics and the Poetics of American Social Movements. Berkeley. Rokkan S. 1975. Dimensions of State Formation and Nation Building: A Possible Paradigm for Research on Variations within Europe. - Tilly C. (ed.) The Formation of National States in Western Europe. Princeton.

Rothstein B. 1996. The Social Democratic State: The Swedish Model and the Bureaucratic Problem of Social Reforms. Pittsburgh.

Rustow D. 1956. Scandinavia. — Neumann S. (ed.) Modern Political Parties. Chicago.

Rustow D. 1970. Transitions to Democracy: Towards a Dynamic Model. — Comparative Politics, vol. 2 , № 3.

Salvatorelli L. 1970. The Risorgimento: Thought and Action. N.Y.

Sarkar S. 1993. Green-Alternative Politics in West Germany. New Delhi.

Schneider C. 1995. Shantytown Protest in Pinochet’s Chile. Philadelphia.

Snowden P. 1953. Socialism and Syndicalism. L.

Sorel G. 1961. Reflections on Violence. N.Y.

Sorel G. 1975. Materiaux d'une theorie du proletariat. N.Y.

Steigerwald D. 1995. The Sixties and the End of Modern America. N.Y.

Steiner J. 1974. Amicable Agreement Versus Majority Rule: Conflict Resolution in Switzerland. Chapel Hill.

Stokes S. 1995. Cultures in Conflict: Social Movements and the State in Peru. Berkeley.

Tarrow S. 1994. Power in Movement: Social Movements, Collective Action and Politics. Cambridge.

Thomas K. 1978. The United Kingdom. — Grew R. (ed.) Crises of Political Development in Europe and the United States. Princeton.

Thompson E.P. 1968. The Making of the English Working Class. Harmondsworth.

Thompson D. 1943. The Democratic Ideal in England and France. L.

Thomson D. 1960. England in the Nineteenth Century. L.

Uyehara 1959. Leftwing Social Movements in Japan: An Annotated Bibliography for the Fletcher School of Law and Diplomacy. Tokyo.

Weber E.J. 1976. Peasants into Frenchmen. Stanford.

West G., Blumberg R. (eds.) 1990. Women and Social Protest. N.Y.

Wohl R. 1966. French Communism in the Making. 1914 - 24. Stanford. 
Wright G. 1960. France in Modern Times. 1760 to the Present. Chicago.

Перевод с английского Л.А.Галкиной и С.С.Сергеевой

Общий анализ социальных движений см. Tarrow 1994; Bash 1995; Morris, Mueller 1992; Snowden 1953; Sorel 1961, 1975; Elliot 1968; Joll 1964. Об истории различных движений в отдельных странах Азии см. Mathew 1968; Kesanvanarayana 1976; Apter 1994; Bennett 1976; Koury 1870; Uyehara 1959); Латинской Америки - La Botz 1995; Assies 1992; Schneider 1995; Stokes 1995; Западной Европы - Della Porta 1995; Sarkar 1992; Boggs 1986; Восточной Европы - Joppke 1995; Opp 1995; Brovkin 1994; Kostunica 1985; Северной Америки - Steigerwald 1995; Jackson 1992; Berry 1992; Reed 1992; Morgan 1991; Goldberg 1991.

2 О “новых социальных движениях” см. Aronowitz 1992; Karst 1993; Banks 1981; West, Blumberg 1990; Jelin 1990; Pizzorno 1994.

3 _ Далее по тексту даны лишь минимально необходимые ссылки на литературу по данной проблематике. Более подробный обзор работ по Франции см. Bien, Grew 1978; Thomson 1943; Lorwin 1954; Weber 1976; Hoffman 1962; Wohl 1966; Pitts 1963; Wright 1960; Luethe 1957; по Германии — Gillis 1971, 1978; Neumann 1956, 1962; Hamerow 1958, 1969; Craig 1955. 


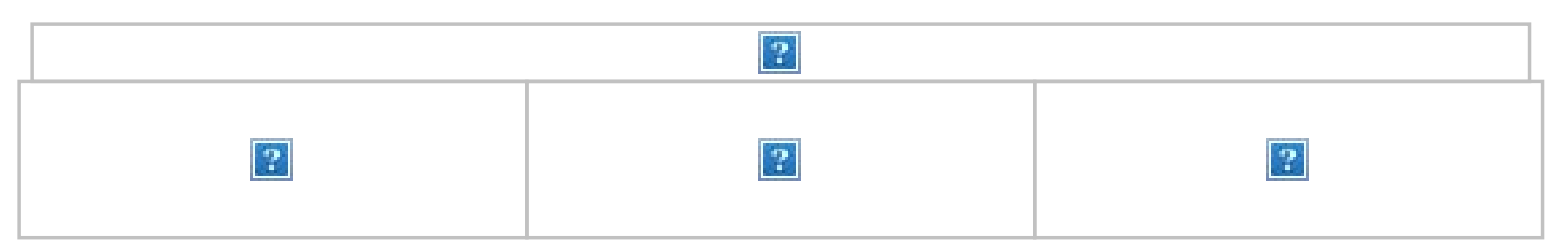

Парадокс демократических режимов: хрупкость и изменяемость (II)

\section{Ш.Н. Эйзенштадт}

Эйзенштадт Шмуэль Н., профессор Еврейского университета в Иерусалиме (Израиль).

Eisenstadt S.N. The Paradox of Democratic Regimes: Fragility and Transformability. - Sociological Theory, 1998, vol. 16, № 3 .

Окончание. Начало см. “Полис”, 2002, № 2, с. 67-81.

\section{Политический процесс в современных обществах: протестные движения и переопределение границ пространства политики}

Для того чтобы полностью постичь суть трений, характерных для динамики современных политических режимов, и прежде всего конфликта между хрупкостью и непрерывностью существования конституционно-демократических порядков, необходимо учитывать, что эти трения тесно связаны с рядом особенностей политического процесса, развивающегося в рамках таких режимов, в частности с постоянным взаимодействием центров и периферий и включением в основную символику современных режимов протестных символов.

Особое значение в данном контексте имеет центральная роль социальных движений, которые часто артикулируют дихотомии, противоречия и темы протеста, присущие позициям критиков и противников программы современности. Подобные движения представляют собой трансформировавшиеся в соответствии с современными условиями модификации различных еретических течений, традиционных для осевых цивилизаций, - прежде всего тех, которые стремились посредством политического действия добиться претворения или воссоздания на Земле Царства Божьего. Многие из них воплощают в себе поиск путей, способных приблизить некий конкретный общественный и политический строй к состоянию идеала, и такой поиск является важнейшим (хотя, конечно, не единственным) компонентом современного политического дискурса и процесса. Указанные движения - один из главных, а быть может, и главный носитель утопических представлений в современных обществах. Именно в них утопическое измерение современной политической жизни обнаружило свою сопряженность как с политическими структурами современности, так и с политическим плюрализмом. Отмеченная тенденция прямо коррелирует с харизматизацией центра как той ключевой арены, где подобные взгляды могут и должны найти свою реализацию.

Ведущей целью одной из разновидностей упомянутых движений было преобразование центров соответствующих обществ_1 . Среди движений такого типа были и видевшие свою задачу в изменении принципов и оснований распределения власти в собственных обществах. Доминирующую роль в новейшие времена играли: (1) движения, добивавшиеся расширения круга лиц, включенных в центральную политическую структуру (посредством расширения избирательного права), и (2) социалистические и коммунистические движения, которые, наряду с этим, выступали за перестройку самой политэкономической модели. Предполагалось, что последнее может быть достигнуто путем коренной реорганизации экономических отношений и устранения наиболее иерархических позиций существующих центров. Другая группа движенийстремилась к преобразованию границ политических сообществ - прежде всего национальных или этнических.

В последнее время на авансцену выступили новые типы движений, постепенно усиливающие свою ориентацию на центр_2_. К данной категории относятся женские движения, а также движения всевозможных меньшинств; все они требуют изменения правил, регулирующих доступ к ресурсам и их распределение. В завершающие десятилетия XX в. на центр стали ориентироваться многие фундаменталистские и религиозные общинные движения, причем некоторые из них заняли доминирующие позиции. Подобные движения обычно не только выдвигают свои специфические требования, но и 
отстаивают более широкую, всеобъемлющую систему принципов, часто несущую на себе отчетливый отпечаток якобинства.

Помимо движений, ориентирующихся на центр, возникали и набирали силу религиозно-реформаторские, кооперативные и синдикалистские движения, добивавшиеся изменения тех или иных аспектов жизнедеятельности различных общественных секторов; анархистские движения, отвергавшие государство в принципе, а также популистские движения, делавшие упор на независимое участие [людей] в политическом процессе и выступавшие против господства бюрократии или центра. Для многих из них было характерно полное отрицание базовых посылок современности и их институциональных производных. Некоторые такие движения, в т.ч. уже давно сложившиеся религиозно-реформаторские, а также “синдикалистские” и большинство “постсовременных” (последние будут подробно проанализированы ниже), вроде бы отказались от ориентации на центр. Они были склонны подчеркивать необходимость создания новых [социальных] пространств, независимых от центра, но при этом зачастую посягающих на него. В действительности же эти два типа установок - ориентация на центр и акцент на конструировании новых [социальных] пространств - почти всегда частично совпадали. Конкретные темы, поднятые “отвернувшимися” от центра движениями, впоследствии были перехвачены теми, которые по-прежнему ориентировались на него.

Все эти непрерывно видоизменявшиеся движения существовали бок о бок друг с другом, образуя ключевой элемент политической и социальной динамики и дискурса современности, каким он был с конца XVIII в. Однако, поскольку их представления об общественном и политическом строе расходились, между ними в определенных условиях могли возникать острые идеологические и политические конфликты, как это было в 1930-х годах, когда вспыхнула жестокая идеологическая и политическая борьба между коммунистическим и фашистским движениями, или в период холодной войны, когда столкнулись коммунистическая и демократическая идеологии.

Институциональным фоном для развития рассматриваемых движений и их воздействия на политическую динамику своих обществ служили современные режимы в Европе, а затем - и за ее пределами. Они складывались прежде всего под влиянием процессов индустриализации, становления и экспансии капитализма, образования все новых современных политических режимов, формаций и международных систем и формирования соответствующих данным процессам новых типов коллективности — наций и наций-государств. Вне Западной Европы подобные движения возникали в связи с распространением империалистических, экономических, военных и идеологических аспектов современности по всему миру, а также столкновением между гегемонией Запада, с одной стороны, и традициями и цивилизациями Центральной и Восточной Европы, Азии, Африки - с другой. Указанные институциональные явления создавали не только исторические предпосылки для кристаллизации культурной и политической программы современности, но и ту арену, на которой данная программа - со всеми присущими ей антиномиями, трениями и противоречиями - разворачивалась, обретала законный статус и противостояла постоянно меняющимся социальным условиям. Именно трения и противоречия между базовыми положениями культурной и политической программы современности, а также между этими положениями и реальным ходом событий на различных национальных и международных институциональных площадках и привели к зарождению основных социальных движений.

Ключевая роль описываемых движений была тесно связана с двумя важнейшими особенностями политического процесса (развитию которых данные движения, со своей стороны, способствовали). Речь идет о: (1) потенциально высокой возможности политизации требований, выдвигаемых различными секторами общества, а также возникновения конфликтов между этими требованиями (вероятность такого поворота событий здесь выше, чем при любых других режимах, за исключением разве что тех, которые действовали в некоторых античных городах-государствах) и (2) непрерывной борьбе за переопределение пространства политики.

Тенденция к политизации требований проявляется в непрестанном переплетении борьбы за реализацию конкретных интересов отдельных граждан и групп с борьбой за утверждение конкурирующих толкований общей воли и коллективной идентичности (или идентичностей) [Pizzorno 1994]. С данным феноменом непосредственно связана и наблюдаемая во всех современных режимах мощная тенденция к постоянному пересмотру границ публичной политической сцены. Переход от концепции невмешательства государства в экономику (которая, разумеется, никогда полностью не проводилась в жизнь) к послевоенной кейнсианской модели государственного регулирования и институционализация государства всеобщего благосостояния быть может, лучшая иллюстрация такого пересмотра границ, но это лишь надводная часть айсберга [Maier 
1987; Przeworsky 1985]. На самом деле подобного рода изменения происходили в рассматриваемых обществах на протяжении всей их истории. В отличие от большинства других известных человечеству политических режимов, [в режимах современного типа] установление пределов политического само по себе является одним из главных средоточий публичных политических споров и столкновений.

Как показывает опыт государств всеобщего благосостояния, переопределению границ политического обычно сопутствовали попытки обновить трактовку всеобщего блага. В свою очередь изменение последней, как правило, требовало пересмотра набора прав, предоставляемых членам сообщества в сфере общественного перераспределения частных благ (прежде всего наделения граждан правом доступа к общественным благам), и принципов организации публичного пространства.

Требования перестройки области политического могли порождать (и нередко порождали) многочисленные конфликты и столкновения. Возникали трения между различными трактовками демократии (особенно между якобинскими и плюралистическими компонентами программы современности), противоречия между автономией гражданского общества и мощью государства, легитимационные споры между защитниками конституционных правил игры и носителями “первичных” концепций (выражаемых в примордиальных и/или сакральных терминах), а также расхождения между “рутинными” и “революционными” аспектами политического курса [см. Ackerman 1991; Eisenstadt 1996; Lasky 1970, 1976].

Широкое распространение [социальных] движений, активная артикуляция требований реорганизации сферы политического и постоянный вызов, обусловленный противоречиями между всеобъемлющей, интегралистской, а потенциально — и тоталитарной системой взглядов, с одной стороны, и приверженностью плюралистическим принципам - с другой, были присущи всем современным режимам и являлись базовыми элементами политической динамики в новейшую эпоху. Ни одной из современных конституционных и/или либеральных демократий так и не удалось (да и не могло удаться) полностью избавиться от якобинского компонента, особенно от его утопических аспектов. Они оказались не способны окончательно отказаться от тех составляющих коллективной идентичности, которые были связаны с ориентацией на некие примордиальные или сакральные, религиозные ценности, равно как от той легитимности, какую придают политическому строю подобного рода представления.

Повсеместность описанных выше трений в современных конституционно-демократических режимах свидетельствует о том, что такие режимы сталкиваются с двояким вызовом: идеологическим и конституционным. В первом случае речь идет об отрицании теми, кто отстаивает приоритет всеобей воли, легитимности плюрализма, во втором - о возможности разных толкований всеобщей воли и борьбы сторонников этих толкований за гегемонию. Первый вызов связан с необходимостью обеспечить приверженность ведущих политических акторов существующим правилам игры при сохранении способности режима к инкорпорации протеста в структуры центра, к переопределению рамок политического и, следовательно, к трансформации оснований своей легитимации. Подобная перестройка выражается прежде всего в переоценке границ политической сферы, в пересмотре прав и обязанностей членов сообщества, а также масштабов перераспределения личных благ и уровня доступа к ним. Указанные преобразования могут осуществляться по нескольким, нередко в чем-то пересекающимся направлениям: (1) через реконструкцию или изменение символов коллективной идентичности и центров; (2) через пересмотр по крайней мере некоторых принципов и форм легитимации режимов; (3) через пропаганду и осуществление политического курса, нацеленного на перераспределение ресурсов, и (4) через создание социальных ниш, в рамках которых различные группы смогут культивировать свои особые коллективные идентичности и собственные формы социальной, культурной или экономической активности.

Иначе говоря, второй вызов, с которым сталкиваются современные конституционно-демократические режимы, заключается в необходимости создания и поддержания некой единой для всех структуры, где могли бы конкурировать различные представления о всеобщем благе, не подрывая при этом функционирования системы. Возникает вопрос, на каком фундаменте (или фундаментах) — помимо соблюдения правил игры - строится общественное признание конституционно-демократических режимов? Быть может, им является сама множественность оснований легитимации - до тех пор, пока ни одно из них не преобладает?

Степень способности конституционно-демократических режимов к разрешению подобных противоречий преимущественно посредством своих ключевых институциональных структур или за счет собственного внутреннего изменения и определяет остроту главной угрозы непрерывности их существования. Более того, 
эта способность и олицетворяет собой парадокс изменчивости данной категории современных режимов. Суть дела заключается в том, что любая подобная трансформация, осуществляемая в рамках конституционно-демократических режимов, влечет за собой некую “металегитимацию”, выходящую за пределы установленных правил игры.

\section{Инкорпорация протеста: концепция политики как игры с ненулевой суммой и структурирование доверия в современных обществах}

Итак, способность к инкорпорации тем и символов протеста различных слоев населения в собственную структуру, в т.ч. попытки дать новую трактовку volonte generale, т.е. всеобщей воли, представляет собой как минимум один из важнейших критериев современных режимов, особенно

конституционно-демократических. Именно благодаря такой инкорпорации упомянутые режимы могут быть преобразованы при сохранении своей преемственности и без отказа от своих конституционных основ и принципов демократии.

Однако не все конституционно-демократические режимы в силах противостоять подобным вызовам. Многие (например США во время Гражданской войны или страны Центральной Европы в 1930-е годы) сбились с магистрального пути как раз потому, что оказались не в состоянии осуществить такую инкорпорацию. Сказанное подтверждает, что сложность и изменчивость проблем, вокруг которых разворачивается политическая борьба, многообразие целей, постоянный пересмотр границ политического обуславливают хрупкость и нестабильность конституционно-демократических режимов. Все эти процессы усугубляют проблему, на которую в свое время указывал А.Пшеворский [Przeworsky 1986, 1989; см. также O’Donnel, Schmitter 1986]: сам характер политической борьбы в таких режимах предполагает неопределенность результатов любого политического спора, любых конкретных выборов, любой дискуссии относительно проведения того или иного политического курса. Другими словами, никто из участников политической игры, ни одна из групп нынешних или потенциальных правителей не могут быть уверены в благоприятном для себя исходе политической схватки. В лучшем случае они могут рассчитывать на то, что им будет предоставлен шанс добиться своего на следующей стадии политического процесса. Инкорпорация новых тем и символов протеста, а также требований пересмотра границ политического, что, в свою очередь, неизбежно влечет за собой перераспределение ресурсов и изменение соотношения сил различных общественных групп и секторов, конечно, усиливает такую неопределенность. Одновременно все большую остроту приобретает вопрос о том, что именно должно побуждать политических акторов к добровольному отказу от своих властных позиций. Но, как ни парадоксально, породить подобную готовность может сама открытость современной политической игры.

При большинстве режимов политическая борьба обычно трактуется как относительно постоянная игра с нулевой суммой, когда выигрыш одного или группы игроков уравновешивается потерями соперников. Однако в современных конституционных демократиях диапазон потенциальных политических целей расширился до такой степени, что способен изменить сам характер политической игры. Конечно, в каждый конкретный период и в каждом конкретном демократическом обществе набор таких целей не безграничен, и одни проблемы оказываются в центре политической борьбы, тогда как другие отходят на задний план или исключаются. Самое общее ограничение диапазона целей касается проблемы соотношения между капитализмом и конституционной демократией. Конституционно-демократические режимы часто критикуются - преимущественно левыми - за то, что они так и не смогли подняться над капиталистическим строем. Вместе с тем некоторые - главным образом, из числа правых (по крайней мере, так было до недавних пор) - утверждают, что рыночная экономика является непременным условием существования конституционно-демократических режимов. Не вдаваясь здесь в подробный анализ этого принципиального и сложного спора, отмечу лишь тот факт, что капиталистические режимы конца XX столетия далеко отошли от тех образцов, которые были приняты на излете XIX и в начале XX в. Во всяком случае они были “приручены” социальными движениями (прежде всего - социалистическими) и под их влиянием подверглись настолько глубокой трансформации, что это повлекло за собой изменение набора политических целей и самого пространства политики в обществе. Подобные перемены указывают на возможность постоянного расширения масштабов политической игры.

Суть парадокса в том, что, хотя расширение рамок политической игры внесло в нее совершенно новый элемент - неопределенность, — который действительно может увеличить хрупкость рассматриваемых режимов, это расширение способно также изменить характер политической игры, превратив ее в игру с ненулевой суммой; и в случае ее принятия в таком качестве будет минимизирована возможность тотального 
поражения любой из сторон. Развитие данной концепции, которое неизбежно повлечет за собой прочную ориентацию на открытость будущего, в состоянии стимулировать политических акторов к передаче власти в соответствии с конституционными правилами игры. Хотя вследствие инкорпорации новых требований и пересмотра границ политического они могут утратить свои властные позиции, их гибкость в дальнейшем позволит им вернуться к власти, дабы воплощать в жизнь собственные представления и добиваться новых целей.

Таким образом, общества, где возникает и укореняется понимание политики как игры с ненулевой суммой, обычно обретают способность к инкорпорации протестных символов и различных требований, особенно если они касаются перестройки пространства политики. Это увеличивает потенциальную изменяемость конституционно-демократических режимов и тем самым позволяет им лучше справляться с главными вызовами, ставящими под угрозу непрерывность их существования.

Установление конституционно-демократических режимов и принятие конституций сами по себе отнюдь не гарантируют развития представлений о политике как об игре с ненулевой суммой и соответствующих возможностей для инкорпорации протеста. Детальный анализ условий, способствующих или препятствующих утверждению подобных представлений и непрерывности существования [конституционно-демократических режимов], выходит за рамки настоящего очерка. Однако представляется уместным высказать ряд предварительных соображений относительно характера этих условий.

Некоторые условия, или предпосылки, демократии подробно проанализированы в научной литературе. Главный упор обычно делается на: (1) распределение ресурсов и власти в обществе, прежде всего на обеспечение различных акторов постоянным доступом к ресурсами, необходимым для вступления в политическую игру и ее проведения; (2) отношения между основными центрами общественной и экономической власти и центральными политическими институтами и аренами; (3) создание и “воспроизводство” автономных публичных сфер.

Важнейшей среди перечисленных в первом пункте данного перечня переменной является положение о недопустимости монополизации ключевых ресурсов и источников власти в обществе какой-либо группой или сектором; это предполагает обязательное наличие множества различных властных центров, которые потенциально способны оставаться вне сферы влияния политической власти (будь она абсолютистской, республиканской или революционно-коммунитарной), но которые - тоже потенциально — имеют доступ к центрам своих обществ. Другим критически значимым условием непрерывности существования конституционно-демократических режимов выступает постоянное расширение независимого доступа социальных групп к политической сцене (или сценам), причем речь идет не только о формальном избирательном праве, но и о реальной возможности прямого участия и/или влияния. Для того чтобы обеспечить такой доступ, необходимы развитие и постоянное функционирование институциональных структур и организаций, служащих связующими звеньями между общественными секторами и политической сценой. Особую роль в данном контексте играют автономные публичные арены, не встроенные ни в государственные структуры, ни в “установленные” статусные или корпоративные рамки какого-либо из общественных секторов. Кроме того, дабы гарантировать их непрерывное развитие, требуется, чтобы они были свободны от контроля со стороны государства, хотя те, кто на них действует, могут иметь доступ к последнему. Наиболее важными из указанных “арен” являются ключевые органы политического представительства и политической организации, такие как партии и другие типы политических ассоциаций, а также каналы коммуникации и дискурса, по которым движется политически значимая информация.

Постоянный процесс публичной коммуникации внутри и между подобными общественными площадками и объединениями, а также - на другом уровне - между ними и центрами облегчает свободный выход основных секторов общества на политическую сцену. Наличие указанных механизмов обеспечивает их постоянное участие [в политической жизни] и способность требовать отчета от правителей.

Значение рассмотренных выше условий для поддержания непрерывного существования конституционно-демократических режимов детально проанализировано, но их воздействие на развитие представлений о политике как об игре с ненулевой суммой еще систематически не исследовано. Я полагаю, что критически важную роль в формировании и развитии подобных представлений играет постоянное воссоздание солидарности и доверия, связывающих между собой различные слои общества, а их — c центрами и институтами, олицетворяющими собой более широкие институциональные площадки. 
Солидарность и доверие не приходят сами собой, особенно в демократических режимах. Приведу в данной связи мнение М.Уоррена, высказанное им в частной переписке: “Парадокс в том, что соотношение между демократией и доверием далеко не однозначно. Конфликты указывают на то, что доверие отсутствует, а быть может — и нецелесообразно; но, тем не менее, любые попытки разрешить их по принципу игры с ненулевой суммой строятся на постулатах о том, что (а) конфликт сдерживается другими отношениями (и институтами), которые включают в себя доверие, и (б) сам процесс урегулирования конфликта порождает доверие. При отсутствии такой возможности демократия оказывается в лучшем случае непрочной”.

Таким образом, возможность постоянного восстановления доверия при демократических режимах определяется особым институциональным фоном - прежде всего наличием относительно стабильных институциональных структур, которые обеспечивают участие основных социальных секторов в выработке и интерпретации правил политической игры. В свою очередь, образование подобного фона зависит от комбинации упомянутых выше структурных факторов, т.е. (1) автономности, сплоченности и доступности центра; (2) открытости основных элит по отношению друг к другу, а также по отношению к более широким слоям населения и (3) четкости и прозрачности построения в соответствующем обществе коллективной идентичности. Здесь я хотел бы сосредоточить внимание на анализе одной из только что перечисленных групп факторов, а именно на способах определения символических границ возникающих общностей современного типа. В данной связи наибольший интерес представляет вопрос о том, в какой мере в том или ином сообществе переплелись между собой примордиальные, религиозные, гражданские и универсалистские компоненты коллективной идентичности и, что особенно важно, не был ли какой-то из них абсолютизирован и противопоставлен своими сторонниками другим компонентам. Во всех современных европейских обществах самыми значимыми с точки зрения долговечности или краха конституционных режимов аспектами установления границ сообщества и выработки коллективной идентичности были формы соединения современных универсалистских и гражданских компонентов последней не только с ее более древними, религиозными составляющими, но и с примордиальными элементами, переосмысленными и преобразованными в ходе процесса модернизации в национальные и/или этнические.

Как показали С.Липсет и С.Роккан [Lipset, Rokkan 1967; Rokkan 1975], существует тесная корреляция между конкретными способами установления границ сообщества, а также соотношением различных компонентов коллективной идентичности и тем, каким образом [в том или ином случае] преодолевались великие религиозные расколы и схватки периодов Реформации и контрреформации и решалась проблема взаимоотношений между национальными, цивилизационными и религиозными общностями. Кроме того, на характер коллективной идентичности повлияли такие факторы, как открытость или, наоборот, жесткость современных центров и сформировавшихся внутри них элит.

Использование одной из моделей “урегулирования”, получившей распространение во Франции и особенно - в Германии____, привело к тому, что религиозный вопрос (раскол между католиками и протестантами или традиционными религиозными группами и “секуляристами”) стал причиной постоянной концентрации внимания на разногласиях и источником политической борьбы между довольно жесткими конкурирующими центрами, а также между соперничающими элитами по вопросам, касающимся построения символов коллективной идентичности и степени независимости религиозных групп в сферах образования и заключения браков. Для другой модели решения религиозной проблемы, принятой преимущественно в католических странах, где взяла верх контрреформация, — прежде всего в Испании, Португалии и во многих областях Италии, — было характерно провозглашение католических символов и институциональных структур единственно допустимыми для данной национальной общности, что, соответственно, повлекло за собой подавление религиозных меньшинств [см. Grew 1963, 1978; Magnone 1961; Delzell 1965; Salvatorelli 1970; Beals 1971; Payne 1978; Derrick 1959].

Оба указанных подхода резко контрастировали с теми, которые использовались в протестантских странах Западной Европы, где успешно институционализировались конституционные режимы. Всем этим странам была присуща относительная, или частичная, деполитизация религиозного раскола, что привело, с одной стороны, к провалу попыток насадить единомыслие, свойственное некоторым протестантским сектам, и, следовательно, к ослаблению интегралистских ориентаций, а с другой - к укреплению эгалитарных и индивидуалистических компонентов, которые были сильны в других протестантских группах.

Как уже упоминалось, описанные модели “урегулирования” религиозных конфликтов во многом коррелировали с типами коллективной идентичности в соответствующих европейских обществах. Так, для 
строения коллективных идентичностей, сложившихся в Англии, Голландии, Швейцарии и Скандинавских странах, характерно тесное переплетение гражданских и универсалистских компонентов с

примордиальными и религиозными (без отвержения последних); вот почему там возникло относительно широкое пространство для плюралистических механизмов [Graubard 1986; Kuhnle 1975; Rothstein 1996; Rustow 1956; Thomas 1978; Thompson 1968; Thompson 1943, 1960; Geyl 1958; Beloff 1954; Daalder 1971; Bergier 1974; Lehmbruch 1972; Lorwin 1971; Steiner 1974]. В этих странах сравнительно успешно, пусть и не без некоторых трений, сосуществовали и перемешивались между собой примордиальные и территориально-этатистские концепции и символы коллективной идентичности и развивались сильные центры, внутри которых важную роль играли представительные институты. Различные элиты и носители конкурирующих концепций были инкорпорированы в основную конституционную структуру общества и действовали по ее правилам.

Подходы к урегулированию религиозного конфликта повлияли и на то, в какой мере [в том или ином обществе] “традиционно” религиозные и/или интегралистские революционные ориентации воспринимались в качестве своего рода неизбежных монополий — и необходимого условия создания символов коллективной идентичности. В протестантских странах придерживавшимся подобных ориентаций институтам, таким как церковь или отдельные политические партии, было отказано в праве вето при определении границ сообщества. Ни религиозные, ни революционные символы или установки никогда не оказывались там в центре постоянных споров по поводу выработки коллективной символики (хотя, разумеется, трения между ними всегда сохранялись), а сами подобные споры обычно разрешались в рамках недавно оформившихся государств и современных конституционных институтов. Иными словами, религиозные и революционные ориентации и символы постепенно переплетались между собой, а также с примордиальными и гражданскими компонентами легитимации, что вело к ослаблению их интегралистских и абсолютистских элементов.

В некоторых обществах — особенно в Центральной Европе и прежде всего в Германии — процесс формирования коллективной идентичности современной нации-государства сопровождался постоянной конфронтацией между примордиальными, гражданскими и универсалистскими компонентами, а также между религиозными группами и “традиционно” религиозными и современными универсалистскими элементами. В этих случаях возникала устойчивая тенденция к кризисам и сбоям в функционировании различных типов конституционных механизмов. Трения между носителями примордиальных и интегралистских компонентов коллективной идентичности дали толчок к появлению движений, абсолютизировавших ту или иную ориентацию, приписывая ей доминирующую роль. Примордиальные элементы возобладали в самых “традиционалистских” авторитарных режимах и в тоталитарных (фашистских или национал-социалистских) движениях с отчетливой расистской окраской; абсолютистские универсалистские концепции распространялись разнообразными “левацкими” якобинскими движениями.

Подобное противостояние часто отражало расхождения между участнической и плюралистической трактовками демократии, тем более что для первой нередко характерны якобинские установки и тяготение к авторитаризму и тоталитаризму. О том, какие проблемы порождает постоянная конфронтация якобинских и традиционалистских составляющих легитимации современных режимов - даже при относительно прочном государственном устройстве и наличии устойчивых коллективных идентичностей и границ, — яснее всего говорит, наверное, опыт Франции. Прежде всего этот опыт указывает на то, что в таких условиях крайне затруднено развитие плюралистических тенденций и структур. Соответственно, институционализация стабильного конституционно-демократического режима здесь проблематична или, в лучшем случае, протекает весьма бурно.

Поскольку конкретные модели выстраивания коллективной идентичности в европейских странах складывались на основе постоянной обратной связи, они тесно коррелировали со степенью автономии центров, а также открытости и доступности таких центров для элит и различных социальных слоев. Оба последних фактора - то есть открытость и доступность - имеют ключевое значение для формирования и перестройки институциональных структур конституционной демократии, особенно когда речь идет о постоянном воспроизводстве публичной сферы (или сфер), автономной от государства и в то же время имеющей независимый выход на политическую сцену, пусть даже характер этой сферы (или сфер) определяется спецификой того общества, в котором она действует, и происходящих в нем изменений.

Различные комбинации рассмотренных выше факторов играют решающую роль в процессе формирования и восстановления доверия между гражданским обществом и государством. Не менее решающей является их 
роль в успешном распространении в обществе отношений доверия, необходимых для становления и поддержания представлений о политике как об игре с ненулевой суммой, а следовательно — для устойчивости конституционных демократий. От комбинации данных факторов зависит, насколько велики окажутся шансы на то, что на любом этапе глубоких социальных трансформаций (1) изменение соотношения компонентов коллективной идентичности и основ легитимации политического режима будет происходить без тотальной конфронтации между отдельными общественными секторами; (2) не прекратится развитие определенных базовых ориентаций, подготавливающих почву для формирования единой коллективной идентичности либо признания различными слоями населения некой всеобщей идеи, или “текста”. Именно появление такого всеобщего “текста”, в сочетании с дисперсией властных центров и рассредоточением власти, богатства и престижа, и способствует постоянной перестройке сферы политического в рамках существующих конституционных институтов. Кроме того, с его появлением складываются благоприятные условия для непрерывного переосмысления и уточнения правил политической игры, а следовательно - для металегитимации этих правил.

Относительная значимость описанных выше факторов и концепций организации власти - например, синхронности создания политических центров и различных общностей — может существенно варьировать в зависимости от страны и конкретных исторических обстоятельств. Прежде всего, нередко неодинаковой бывает роль внутренних и внешних предпосылок создания тех рамок, в которых происходит выработка необходимых [для существования конституционно-демократических режимов] навыков и привычек. В самом деле, один из наиболее интересных феноменов нашего времени, который, однако, во многом воспроизводит прежний исторический опыт, заключается в огромном воздействии международного окружения (в частности, исходящего от него давления в направлении демократизации) на формирование соответствующих структур - даже в ситуациях, когда внутренние предпосылки к этому сравнительно слабы.

Вместе с тем наличие указанных факторов само по себе отнюдь не гарантирует, что между задействованными в политическом процессе акторами возникнет то доверие, которое требуется для поддержания непрерывного существования соответствующего режима. Структура такого доверия и его связь с распределением ресурсов часто определяется различного рода историческими случайностями, особенно последствиями того или иного относительно острого внутреннего конфликта, а также воздействием международных событий. Процесс изменения представлений и привычек людей по ходу развития в Европе конституционных режимов, более 30 лет назад проанализированный Д.Растоу [Rustow 1970], а затем - М.Бертоном, Р.Гантером и Дж.Хайли [Burton, Gunther, Highley 1992], имел первостепенное значение для обретения и утверждения доверия.

Непрерывное воссоздание доверия, а следовательно - и выработка представлений о политике как об игре с ненулевой суммой и обусловленная этим изменяемость конституционно-демократических режимов всегда происходили под влиянием вышеперечисленных факторов. Однако конкретное соотношение указанных факторов, равно как и конкретные модели формирования доверия в целом в различных обществах во многом варьируют. В данном разделе основное внимание было уделено моделям, сложившимся в европейских странах. В США, Японии, Индии и Израиле рассмотренные процессы протекали несколько иначе, но их детальный анализ выходит за рамки настоящего очерка.

\section{Социальные изменения, политический процесс и возможность размывания доверия и эрозии публичной сферы при конституционно-демократических режимах: тенденции к разложению демократии в современных обществах}

Специфика в принципе неостановимого развития конституционно-демократических режимов такова, что наличие благоприятных условий для функционирования данных режимов в некие конкретные исторические периоды само по себе не гарантирует непрерывности их существования и воспроизводства. Конечно, успешная институционализация конституционно-демократического строя во многом способствует закреплению такого рода условий, особенно если речь идет о признании легитимности режима, о доверии к правилам политической игры и о понимании политики как игры с ненулевой суммой. Однако в недрах любой конституционной демократии могут развиваться процессы, размывающие их. В самом деле, уже тот факт, что современные общества (и, в частности, основные параметры политического процесса в странах с конституционно-демократическим устройством) претерпевают постоянные изменения, может подорвать некогда благоприятные условия для постоянного восстановления доверия. 
Во-первых, поскольку современные режимы развиваются в обстановке непрестанных перемен и поскольку внутри них происходят социальные, политические и экономические сдвиги, распределение власти в этих режимах тоже может меняться, что ведет к эрозии значительной части существующих властных центров. Более того, те самые меры, которые изначально были нацелены на ослабление имеющихся полумонополистических центров власти (например, меры, связанные с утверждением государства всеобщего благосостояния), нередко до такой степени усиливают властные полномочия различных политических и административных органов государства, что оказываются разрушены многие независимые базы власти. Угроза такого поворота событий в первую очередь ассоциируется с бюрократизацией важнейших сфер общественной жизни, включая область политики; и, как видно из работ А.де Токвиля, К.Маркса и М.Вебера, страх, порожденный призраком подобной бюрократизации, пронизывает современный социальный дискурс. Понятно, что с образованием тоталитарных режимов этот страх получил дополнительные основания.

Вместе с тем перспектива сверхконцентрации власти потенциально связана и с одним из центральных нервов демократического процесса — с производством и распространением информации, с доступом к ней, а также с растущей профессионализацией и “технократизацией” знаний и сведений, имеющих отношение к политическому процессу. Если эксперты и политические лидеры объявят, что знания, которыми они располагают, выходят за пределы понимания широких кругов общественности, и общество с ними согласится, то результатом могут стать распространение политической апатии и отказ от участия в политике вообще. Кроме того, подобная ситуация чревата нарушением равновесия на самой политической сцене, прежде всего соотношения сил различных ветвей власти, и усилением мощи исполнительных органов.

Во-вторых, масштабные перемены зачастую влекут за собой подрыв автономности и самобытности различных элит, центра и разнообразных публичных арен. Попытки пересмотреть границы политического - например, за счет расширения корпуса избирателей - способны привести к эрозии автономных секторов гражданского общества и существующих политических арен, а также помешать перестройке отношений между гражданским обществом и государством. В таких случаях приверженность существующим правилам игры и соблюдению баланса между государством и гражданским обществом может вступить в противоречие с новыми требованиями, выдвигаемыми недавно возникшими социальными силами. Во всех секторах общества, как старых, так и новых, могут возникнуть тенденции к представительству узкокорпоративного или статусного окружения, что ослабит то исходно одобрительное отношение к наличию данных секторов, которое присутствовало при формировании общих структур и центров.

Во всех подобных ситуациях у тех, кто требует пересмотра границ политического, начинает возникать подозрение, что действующие представительные институты не служат общественному благу. Весьма часто носители власти - а нередко ими бывают сильные полумонополистические, олигархические группы активно поддерживают набор прав, прежде всего права собственности, которые обеспечивают им преимущество перед вновь образующимися группами. Новые же группы, оспаривающие приоритет властвующих, склонны доказывать важность другого набора прав, противопоставляя их тому, что они объявляют узкими интересами небольшого клуба, членство в котором зарезервировано, де-юре или де-факто, только за представителями высших классов. Суть подобной позиции, которой, естественно, придерживаются преимущественно левые критики либерально-демократических режимов, отражает знаменитый афоризм А.Франса о том, что нищий, ночующий под мостом, имеет “равные” права с богатым буржуа. В свою очередь “старые” группы пытаются представить себя выразителями общественного блага в противовес “новичкам”, которых они обвиняют в том, что те заботятся только о своих собственных эгоистических интересах — пусть даже разделяемых многими - и стремятся использовать представительные институты для их продвижения.

В таких условиях перестройка гражданского общества практически неизбежно сопровождается конфронтацией между базовыми концепциями демократии - прежде всего между конституциональной и участнической, - а также, в более общем плане, между плюралистическими и якобинскими ориентациями, заложенными в программе современности. Все эти потенциальные повороты событий олицетворяют собой парадокс изменяемости современных конституционных режимов, суть которого, как мы видели, состоит в том, что любая трансформация последних влечет за собой металегитимацию, выходящую за пределы (действующих) правил игры, и в то же время осуществляется через эти самые институции.

Указанные процессы могут дать толчок к частичному изменению режима в странах с демократическим устройством, как это было, например, при переходе от Четвертой к Пятой республике во Франции. 
Аналогичные сдвиги происходили во многих современных обществах: в Соединенных Штатах, Израиле, Индии и - в менее драматической форме - в Европе. Важнейшими компонентами такого рода режимных преобразований являются: (1) ослабление партий и представительных институтов по сравнению с прямыми политическими действиями и непосредственными отношениями различных политических акторов; (2) усиление средств массовой информации и их роли в политическом процессе и (3) повышение значимости исполнительной власти при возможном возрастании полномочий судебной системы.

Подобные изменения режимов непосредственно сопряжены с далеко идущими сдвигами, затрагивающими многие аспекты социального строения современных обществ. Важнейшими рубежами здесь, вероятно, выступают период накануне второй мировой войны и нынешний, “современный” этап, иногда называемый “постсовременным” [Eisenstadt 1988 1993]. К числу наиболее значимых из упомянутых сдвигов относятся: размывание прежних, когда-то относительно четких, строго определенных и единообразных представлений о жизненном пути (и тем самым - границ семьи, сообщества, локальной и социальной организации) и сопутствующая этому тенденция к выпадению большинства важнейших общественных ролей из всеобъемлющей - в рамках данного общества - символической и институциональной среды. Роли, обусловленные родом занятий, семейным положением, полом, местом проживания, все заметнее отделяются от сословных, классовых и партийно-политических региональных структур. Такие роли все больше и больше оформляются в постоянно меняющиеся кластеры с относительно слабой ориентацией на общие структуры и - особенно - на социетальные центры. Переоценка ролей и образование ролевых кластеров, прежде всего профессиональных и гражданских, - взаимосвязанные феномены, равно как и растущее отмежевание политических центров от социальных и культурных сообществ и развитие новых очагов культурной и социальной идентичности поверх существующих политических и культурных границ.

Совокупность этих изменений в символическом определении различных сфер общественной жизни, в сочетании со структурными сдвигами, ведет к усиливающейся диверсификации процесса стратообразования и формированию перекрещивающихся политических, секторальных и профессиональных структур. Для нынешней ситуации характерна гораздо большая степень разобщенности между профессиональной, культурной и политической сферами жизни, чем это было в эпоху “современного”, “индустриального” общества, когда различные страты имели относительно самостоятельные культурные традиции и объединялись лишь вокруг самых общих и широко понимаемых политических символов. Разброс между культурными ценностями отдельных страт существенно сократился, а их стремление к участию во всех проявлениях и областях культурной жизни вообще и массовой культуры — в частности, неуклонно растет.

Таким образом, общественные страты постоянно перестраиваются, трансформируя и видоизменяя свои взаимоотношения и порождая новые формы сопряжения социальной структуры, культуры, политической активности и политической организации. В результате профессионального распыления они по большей части утратили свои всеобъемлющие политико-идеологические ориентации, соответственно, упало и значение той проблематики, вокруг которой разворачивались классовые конфликты и классовая борьба и которая традиционно была сфокусирована на государстве как распределяющей и — в меньшей степени регулирующей инстанцией. Одновременно сократился и раскол между “левыми” и “правыми” в целом и ослабла тесная взаимосвязь между его наличием и перестройкой центра, столь сильно проявлявшаяся в Европе и Японии.

Кульминацией всех описанных выше трансформаций стало изменение характера протестных движений. Начало этому процессу положили студенческие бунты 1960-х годов, а затем он охватил женские и экологические движения, движения сторонников расширения участия работников в управлении производством, борцов за решение тех или иных проблем локальных сообществ, и т.д. В отличие от прежних, “классических”, социальных движений индустриальных обществ эпохи модерна, которые с присущей им конфликтно-идеологической направленностью фокусировали внимание на центре и его перестройке, новые движения ставят во главу угла расширение системного пространства общественной жизни и проблему участия. Наиболее ярким проявлением подобной смены ориентаций был, наверное, перенос акцента с вопросов повышения уровня жизни, что олицетворяло собой суть непрерывного технологическо-экономического прогресса и было так характерно для 1950-х годов, на проблемы улучшения “качества жизни”; в 1970-е годы данная трансформация обозначалась как переход от “материальных” к “постматериальным” ценностям. Все упомянутые движения отвергают логику перестройки центра, сосредоточивая свои усилия на создании новых социальных пространств. Вместе с тем такого рода перемены сами по себе являются показателем другого серьезного сдвига: политический центр, оставаясь главной инстанцией, занимающейся распределением ресурсов, уже утратил ту харизму, которая бы 
позволила ему, как прежде, притягивать к себе основное внимание различных социальных движений или, коли на то пошло, широких слоев общественности.

Указанные перемены прямо коррелируют с возможностью частичного изменения режима, о которой шла речь выше. В наиболее крайних случаях их сочетание способно также привести к тому, что, пользуясь удачным выражением Л.Даймонда [Diamond 1993; см. также Linz, Stepan 1996], можно назвать деконсолидацией институциональных и ассоциативных оснований конституционно-демократических режимов, и - тем самым - к ослаблению или размыванию конституционных компонентов, жизненно необходимых для реализации принципа верховенства права, таких как невмешательство политических органов в общественные и частные дела и т.п.

Как отмечал Р.Дарендорф [Dahrendorf 1990], подобное ослабление или даже размывание основ и принципов гражданского общества наблюдается сегодня во многих современных конституционных демократиях. Например, в странах Латинской Америки [см. Huber, Rueschmeyer, Stephens 1997] описанная тенденция, похоже, проявляется в усилении формальных и ослаблении участнических аспектов демократии. Как ни парадоксально, все это происходит в ситуации, когда идеологические, прежде всего тоталитарные фашистские или коммунистические, — противники конституционной демократии уже сошли с исторической сцены. Аккумуляция данных процессов может породить разочарование и апатию, которые, в свою очередь, способны повлечь за собой подрыв доверия к центральным институтам или — другая крайность - поворот в сторону всевозможных экстремистских движений и развитие новых форм политической активности.

Вполне вероятно, что мы являемся сегодня свидетелями становления — и в конституционно-демократических, и во многих полудемократических, авторитарных режимах по всему миру - новых моделей политической активности, тесно связанных с далеко идущими “культурными” сдвигами, а также с изменением оснований легитимации таких режимов. Однако, хотя эти тенденции и имеют непосредственное отношение к рассматриваемым здесь проблемам, их анализ выходит за рамки настоящего исследования.

Ackerman B. 1991. We The People. Cambridge.

Apter D. 1994. Revolutionary Discourse in Mao’s Republic. Cambridge.

Aronowitz S. 1992. The Politics of Identity: Class, Culture, Social Movements. N.Y.

Assies W. 1992. To Get Out of the Mud. Neighbourhood Associativism in Recife, 1964 - 1988. Amsterdam.

Banks O. 1981. Faces of Feminism: A Study of Feminism as a Social Movement. Oxford.

Bash H. 1995. Social Problems and Social Movements: An Exploration into the Sociological Construction of Alternative Realities. Atlantic Highlands.

Beals D. 1971. The Risorgimento and the Unification of Italy. L.

Beloff M. 1954. The Age of Absolutism: 1660 — 1815. L.

Bennett G. 1976. “Yundong” Mass Campaign in Chinese Communist Leadership. Berkeley.

Bergier J. 1974. Naissance et croissance de la Suisse industrielle. Bern.

Berry B. 1992. America’s Utopian Experiments: Communal Havens from Long-Wave Crises. Hanover.

Bien D., Grew R. 1978. France. - Grew R. (ed.) Crises of Political Development in Europe and the United States. Princeton.

Boggs C. 1986. Social Movements and Political Power: Emerging Forms of Radicalism in the West. Philadelphia.

Brovkin V. 1994. Behind the Front Lines of the Civil War: Political Parties and Social Movements in Russia, 1918 - 1922. Princeton. 
Burton M., Gunther R., Highley J. 1992. Elites and Democratic Consolidation — Latin America and Southern Europe, An Overview. - Highley J., Gunther R. (eds.) Elites and Democratic Consolidation in Latin America and Southern Europe. Cambridge.

Craig G. 1955. The Politics of the Prussian Army. Oxford.

Daalder H. 1971. On Building Consociational Nations: The Case of the Netherlands and Switzerland. — International Social Science Journal, vol. 23.

Dahrendorf R. 1990. The Modern Social Conflict: An Essay on the Politics of Liberty. Berkeley.

Della Porta D. 1995. Social Movements. Political Violence, and the State: Comparative Analysis of Italy and Germany. Cambridge.

Delzell C. (ed.) 1965. The Unification of Italy, 1859 - 1861. N.Y.

Derrick M. 1959. The Portugal of Salazar. L.

Diamond L. 1993. Conclusion. Causes and Effects. — Diamond L. (ed.) Political Culture and Democracy in Developing Countries. Boulder.

Eisenstadt S.N. 1988. Revolutionary Movements and Radicalism in Post-Industrial Societies. — International Foundation of Social Sciences. International Symposium on Fears and Hopes. October.

Eisenstadt S.N. 1993. Small Estates in the "Post-Modern” Era. — Kleinstaat, Lichtenstein Politische Schriften, Bd. 16.

Eisenstadt S.N. 1996. Barbarism and Modernity. — Society, vol. 33, № 4.

Elliot W. 1968. The Pragmatic Revolt in Politics: Syndicalism, Fascism, and the Constitutional State. N.Y.

Geyl P. 1958. The Revolt of the Netherlands. N.Y.

Gillis J. 1971. The Prussian Bureaucracy in Crisis. 1940 - 1860. Stanford.

Gillis J. 1978. Germany. — Grew R. Crises of Political Development in Europe and the United States. Princeton.

Goldberg R. 1991. Grassroots Resistance: Social Movements in Twentieth-Century America. Belmont.

Graubard S. (ed.) 1986. Norden — The Passion for Equality. Oslo.

Grew R. 1963. A Sterner Plan for Italian Unity. Princeton.

Grew R. 1978. Italy. — Grew R. (ed.) Crises of Political Development in Europe and the United States. Princeton. Hamerow T. 1958. Restoration, Revolution, Reaction. Princeton.

Hamerow T. 1969. The Social Foundations of German Unification, 1858 - 1871. Princeton.

Hoffman S. Protest in Modern France. - Kaplan M. The Revolution in World Politics. N.Y.

Huber E., Rueschemeyer D., Stephens J.D. 1997. The Paradoxes of Contemporary Democtacy: Formal, Participatory, and Social Democracy. - Comparative Politics, vol. 29, № 3.

Jackson R. 1992. The 1960s: An Annotated Bibliography of Social and Political Movements in the United States. Westport.

Jelin E. (ed.) 1990. Women and Social Change in Latin America. Geneva.

Joll J. 1964. The Anarchists. L. 
Joppke C. 1995. East German Dissidents and the Revolution of 1989: Social Movements in a Leninist Regime. N.Y. Karst K. 1993. Law’s Promise, Law’s Expression: Visions of Power in the Politics of Race, Gender and Religion. New Haven.

Kesavanarayana B. 1976. Political and Social Factors in Andhra (1900 - 1956). Vijayawada.

Kostunica V. 1985. Party Pluralism or Monism: Social Movements and the Political System in Yugoslavia. 1944 1949. Boulder.

Koury E. 1970. The Patterns of Mass Movements in Arab Revolutionary-Prograssive States. Hague.

Kuhnle S. 1975. Patterns of Social and Political Mobilization: A Historical Analysis of the Nordic Countries. Beverly Hills.

La Botz D. 1995. Democracy in Mexico: Peasant Rebellion and Political Reform. Boston.

Lasky M. 1970. The Birth of a Metaphor: On the Origins of Utopia and Revolution. — Encounter, vol. 34, № 2.

Lasky M. 1976. Utopia and Revolution. Chicago.

Lehmbruch G. 1972. Proporzdemokratie: Politische System und politische Kultur in der Schweiz und in Osterreich. Tubingen.

Linz J.J., Stepan A. 1996. Problems of Democratic Transition and Consolidation. Baltimore.

Lipset S.M., Rokkan S. (eds.) 1967. Party Systems and Voter Alignments. N.Y.

Lorwin V. 1954. The French Labor Movement. Cambridge.

Lorwin V. 1971. Segmented Pluralism. Ideological Cleavage and Political Behavior in the Smaller European Democracies. - Comparative Politics, vol. 3.

Luethe H. 1957. France Against Herself. N.Y.

Magnone G. 1961. Italy. — Cole T. (ed.) European Party Systems. N.Y.

Maier C.S. (ed.) 1987. Changing Boundaries of the Political. Cambridge.

Mathew J. 1986. Ideology, Protest and Social Mobility: Case Study of Mahars and Pulayas. New Delhi.

Morgan E. 1991. The 60s Experience: Hard Lessons about Modern America. Philadelphia.

Morris A., McClurg Muller C. (eds.) 1992. Frontiers in Social Movement Theory. New Haven.

Neumann S. 1956. Germany: Changing Patterns and Lasting Problems. — Modern Political Parties. Chicago.

Neumann S. 1962. The German Political System. — Beer S., Ulam A. (eds.) Patterns of Government: The Major Political Systems of Europe. N.Y.

O’Donnel G., Schmitter P. 1986. Transition from Authoritarian Rule: Tentative Conclusions about Uncertain Democracies. Baltimore.

Opp K. 1995. Origins of a Spontaneous Revolution, East Germany, 1989. Ann Arbor.

Payne S. 1978. Spain and Portugal. - Grew R.(ed.) Crises of Political Development in Europe and the United States. Princeton.

Pitts J. 1963. Continuity and Change in Bourgeois France. — In Search of France. Cambridge (MA). 
Pizzorno A. 1994. Le radici della politica assoluta. Milano.

Przeworski A. 1985. Capitalism and Social Democracy. Cambridge.

Przeworski A. 1986. Some Problems in the Study of the Transition to Democracy. — Transitions from Authoritarian Rule: Comparative Perspective. Baltimore.

Przeworski A. 1989. Democracy as a Contingent Outcome of Conflicts. — Elster J., Slagstad R. (eds.) Constitutionalism and Democracy. Cambridge.

Reed T. Fifteen Jugglers, Five Believers: Literary Politics and the Poetics of American Social Movements. Berkeley. Rokkan S. 1975. Dimensions of State Formation and Nation Building: A Possible Paradigm for Research on Variations within Europe. - Tilly C. (ed.) The Formation of National States in Western Europe. Princeton.

Rothstein B. 1996. The Social Democratic State: The Swedish Model and the Bureaucratic Problem of Social Reforms. Pittsburgh.

Rustow D. 1956. Scandinavia. — Neumann S. (ed.) Modern Political Parties. Chicago.

Rustow D. 1970. Transitions to Democracy: Towards a Dynamic Model. — Comparative Politics, vol. 2 , № 3.

Salvatorelli L. 1970. The Risorgimento: Thought and Action. N.Y.

Sarkar S. 1993. Green-Alternative Politics in West Germany. New Delhi.

Schneider C. 1995. Shantytown Protest in Pinochet’s Chile. Philadelphia.

Snowden P. 1953. Socialism and Syndicalism. L.

Sorel G. 1961. Reflections on Violence. N.Y.

Sorel G. 1975. Materiaux d'une theorie du proletariat. N.Y.

Steigerwald D. 1995. The Sixties and the End of Modern America. N.Y.

Steiner J. 1974. Amicable Agreement Versus Majority Rule: Conflict Resolution in Switzerland. Chapel Hill.

Stokes S. 1995. Cultures in Conflict: Social Movements and the State in Peru. Berkeley.

Tarrow S. 1994. Power in Movement: Social Movements, Collective Action and Politics. Cambridge.

Thomas K. 1978. The United Kingdom. — Grew R. (ed.) Crises of Political Development in Europe and the United States. Princeton.

Thompson E.P. 1968. The Making of the English Working Class. Harmondsworth.

Thompson D. 1943. The Democratic Ideal in England and France. L.

Thomson D. 1960. England in the Nineteenth Century. L.

Uyehara 1959. Leftwing Social Movements in Japan: An Annotated Bibliography for the Fletcher School of Law and Diplomacy. Tokyo.

Weber E.J. 1976. Peasants into Frenchmen. Stanford.

West G., Blumberg R. (eds.) 1990. Women and Social Protest. N.Y.

Wohl R. 1966. French Communism in the Making. 1914 - 24. Stanford. 
Wright G. 1960. France in Modern Times. 1760 to the Present. Chicago.

Перевод с английского Л.А.Галкиной и С.С.Сергеевой

Общий анализ социальных движений см. Tarrow 1994; Bash 1995; Morris, Mueller 1992; Snowden 1953; Sorel 1961, 1975; Elliot 1968; Joll 1964. Об истории различных движений в отдельных странах Азии см. Mathew 1968; Kesanvanarayana 1976; Apter 1994; Bennett 1976; Koury 1870; Uyehara 1959); Латинской Америки - La Botz 1995; Assies 1992; Schneider 1995; Stokes 1995; Западной Европы - Della Porta 1995; Sarkar 1992; Boggs 1986; Восточной Европы - Joppke 1995; Opp 1995; Brovkin 1994; Kostunica 1985; Северной Америки - Steigerwald 1995; Jackson 1992; Berry 1992; Reed 1992; Morgan 1991; Goldberg 1991.

2 О “новых социальных движениях” см. Aronowitz 1992; Karst 1993; Banks 1981; West, Blumberg 1990; Jelin 1990; Pizzorno 1994.

3 _ Далее по тексту даны лишь минимально необходимые ссылки на литературу по данной проблематике. Более подробный обзор работ по Франции см. Bien, Grew 1978; Thomson 1943; Lorwin 1954; Weber 1976; Hoffman 1962; Wohl 1966; Pitts 1963; Wright 1960; Luethe 1957; по Германии — Gillis 1971, 1978; Neumann 1956, 1962; Hamerow 1958, 1969; Craig 1955. 